Quaestio facti. Revista Internacional sobre Razonamiento Probatorio Quaestio facti. International Journal on Evidential Legal Reasoning Vol. 1 | 2020 pp. 301-355 Madrid, 2020

DOI: $10.33115 /$ udg_bib/qf.i0.22377 Marcial Pons Ediciones Jurídicas y Sociales

(C) Gary Edmond ISSN: 2604-6202

Recibido: 20/06/2019 | Aceptado: 22/10/2019

\title{
CUANDO EL DERECHO ES POCO FIABLE: RESPUESTAS JURÍDICAS A LA PRUEBA DE HUELLAS DACTILARES LATENTES
}

\author{
Gary Edmond* \\ Profesor de la Escuela de Derecho de la UNSW, Sidney, Australia \\ g.edmond@unsw.edu.au
}

RESUMEN: A partir de casos reportados, este ensayo busca evaluar el impacto que han tenido en la respuesta jurídica que se ha dado a las pruebas mediante huellas dactilares latentes las reglas de admisibilidad, las garantías procesales (incluidas las apelaciones), los cambios en las reglas de admisibilidad y de procedimiento y el surgimiento de asesoramiento científico exógeno. Centrado en decisiones judiciales reportadas en cuatro jurisdicciones del common law, Inglaterra y Gales, Estados Unidos, Canadá y Australia, este ensayo examina la abrumadoramente complaciente respuesta a este tipo de prueba científico forense.

PALABRAS CLAVE: Huellas dactilares latentes; prueba dactilar; ciencias forenses; criterios de admisibilidad de la prueba; prueba pericial.

\section{UNRELIABLE LAW: LEGAL RESPONSES TO LATENT FINGERPRINT EVIDENCE}

\footnotetext{
ABSTRACT: Drawing on reported cases this essay endeavors to assess the impact of admissibility rules, trial safeguards, changes to admissibility and procedural rules, and the emergence of exogenous

* Esta investigación fue apoyada por el ARC (LP16010000). Me gustaría agradecer a Simon Cole por sus comentarios y sugerencias.

Traducción de Andrés Fuchs, revisada por Carmen Vázquez. Juan Carlos (antonio.pastor@urjc.es) y consultor de HSF. Todas las páginas web de referencia han sido consultadas por última vez el 30 de junio de 2017.
} 
scientific advice, on legal responses to latent fingerprint evidence. Focused on reported decisions in four common law jurisdictions, namely England and Wales, the United States, Canada and Australia, the essay examines the overwhelmingly accommodating response to this forensic science evidence.

KEYWORDS: Latent fingerprint evidence; fingerprint evidence; forensic science evidence; admissibility rules; expert evidence.

SUMARIO: 1. Introducción (a una revisión histórica comparada). 1.1 Algunas advertencias.-2. Reconocimiento: admisión y uso temprano, desde 1909 a 1923 (en Canadá, no obstante, hasta 1946). 2.1. Inglaterra y Gales: R v. Castleton (1909) y R v. Bacon (1916). 2.2. Estados Unidos: People v. Jennings (1911) y State v. Cerciello (1914). 2.3. Australia: Rex v. Blacker (1910) y R. v. Parker (1912). 2.4. Canadá: una aberración temporal (hasta R. v. Buckingham). 2.5. Resumen.—3. Consolidación: Un siglo de impugnaciones no epistémicas (1909-1998 y después). 3.1. Admisibilidad y otras impugnaciones en los Estados Unidos. 3.2. Admisibilidad y otras impugnaciones en el Reino Unido. 3.3. Admisibilidad y otras impugnaciones en Australia y Canadá. 3.4. Resumen.—4. Nuevas reglas, «revoluciones» en la admisibilidad y condenas erróneas (1975 - 2009). 4.1. Estados Unidos: Las FRE (1975), los perfiles de ADN y Daubert (1993). 4.2. Inglaterra y Gales: La Comisión Real de Runciman, $R$ v Buckley (1999), el Servicio de Ciencias Forenses, las Criminal Procedure Rules, las Crimiminal Practice Directions y los informes forenses simplificados. 4.3. Canadá: R. v. Mohan, R. v. Abbey (y White Burgess) y condenas erróneas (por ejemplo, Re Truscott y las investigaciones de Kaufman y Goudge). 4.4. Australia: Chamberlain (y Splatt), la UEL y más de lo mismo. 4.5. A manera de reseña.-5. Bibliografía.

\section{INTRODUCCIÓN (A UNA REVISIÓN HISTÓRICA COMPARADA)}

A partir de casos reportados ${ }^{*}$, este ensayo busca evaluar el impacto que han tenido las reglas de admisibilidad, las garantías procesales de los juicios orales (incluidas las apelaciones), los cambios en las reglas de admisibilidad y de procedimiento y el surgimiento de asesoramiento científico exógeno en la reacción jurídica a las pruebas científico forenses, específicamente las pruebas de huellas dactilares latentes ${ }^{1}$. Partiendo en la primera década del siglo xx, y en la medida que comenzaban a conformarse oficinas de huellas dactilares en las democracias sociales más avanzadas, este ensayo analiza cómo los tribunales de primera instancia y los tribunales de apelación respondieron a la aparición de pruebas de huellas dactilares latentes en procesos penales y en las decisiones condenatorias. Centrado en decisiones judiciales reportadas en cuatro jurisdicciones del common law, Inglaterra y Gales, Estados Unidos, Canadá y Austra-

\footnotetext{
* Nota de traducción: El autor se refiere a la serie de los «Law Reports» que compilan decisiones judiciales y proveen el grueso del derecho. Por ello, hemos decidido utilizar la expresión «casos reportados».

1 Este ensayo se basa, y ojalá expanda las ideas e implicaciones incluidas en las obras de Cole (2001) y Risinger (2000).
} 
lia, este ensayo examina la abrumadoramente complaciente respuesta a este tipo de prueba científico forense, desde sus inicios hasta la actualidad ${ }^{2}$. A través de ejemplos se demuestra en este ensayo una insensibilidad jurídica persistente al conocimiento científico y la fiabilidad real de las pruebas dactilares.

Al mantener la atención en la admisión y en la forma de la prueba de huellas dactilares latentes a lo largo del siglo xx y más allá, en tanto que iban cambiando las normas jurisdiccionales de admisión y del procedimiento, en la medida en que se introducían nuevos procedimientos y tecnologías sobre huellas dactilares (por ejemplo el AFIS) y comenzaba lentamente la investigación científica sobre el tema, este análisis histórico permite evaluar en qué medida las salvaguardas jurídicas y los mecanismos probatorios permitieron a los abogados y a los jueces (y a otros responsables de la toma de decisiones) apreciar algunos de los problemas, limitaciones e incertidumbres emergentes de las pruebas de huellas dactilares latentes ${ }^{3}$. Es muy revelador que solo hasta el final del milenio encontremos los primeros intentos serios de cuestionar los presupuestos subyacentes a la prueba de huellas dactilares (en particular la importancia de la unicidad), el valor de los procedimientos empleados (por ejemplo, la cantidad de puntos y el ACE-V) y los reclamos sistemáticos sobre las identificaciones categóricas (o individualizaciones), junto con reclamos ubicuos sobre afirmaciones de obtención de resultados libres de errores ${ }^{4}$. No fue sino hasta finales del siglo xx, casi cien años después de que se admitiera y confiara en la prueba dactilar latente, que unos pocos tribunales comenzaron a considerar cuestiones epistemológicas -sobre su validez, su fiabilidad científica y la pericia de los examinadores de huellas dactilares 5 . Como veremos, estos desafíos de orientación epistemológica, que exponen una serie de descuidos y problemas metodológicos serios, casi no tuvieron impacto en la forma en que los tribunales siguieron admitiendo esta prueba pericial y en decenas de miles de casos penales se ha confiado en la prueba dactilar, a veces incluso como la única prueba para determinar la identidad y la culpabilidad del acusado.

2 Las decisiones reportadas parecen apropiadas porque suelen ser los casos más relevantes y, quizás más importante, son el recurso con que cuentan los abogados, jueces, comentaristas legales e incluso (en diversos grados) los profesionales forenses para entender la ley y su importancia probatoria.

3 AFIS se refiere a Automated Fingerprint Identification System [en español: Sistema Automático de Identificación Dactilar]. A veces el prefijo $\mathrm{N}$ es utilizado para referirse a sistemas nacionales-i.e. NAFIS.

4 ACE-V es el método dominante para análisis de huellas dactilares. El acrónimo corresponde a "Analysis, Comparison, Evaluation, and Verification" [en español: análisis, comparación, evaluación y verificación].

5 La discusión distingue entre impugnaciones sustanciales (o basadas en la epistemología) y otro tipo de impugnaciones a la prueba dactilar. Las impugnaciones sustanciales están generalmente enfocadas, aunque no exclusivamente, en la admisibilidad de este tipo de pruebas poniendo la atención en cuestiones metodológicas fundamentales, asociadas con el procedimiento científico y su nivel de certeza. El otro tipo de impugnaciones tiende a estar enfocada en cuestiones jurídicas o procesales, tales como si la prueba es admisible o no en consideración a las circunstancias en que fueron tomadas las huellas del acusado. La mayoría de las impugnaciones jurídicas no se preocupan del grado de certeza en la comparación de las huellas dactilares. Estas impugnaciones no es que sean menos importantes o tengan menos éxito, pero tienden a ser epistemológicamente superficiales y, por tanto, tienden a dar por sentado el valor probatorio de la prueba dactilar. (Las categorías son heurísticas y sus contornos no son siempre claros, teniendo grados de superposición). 
Estas ideas son esclarecedoras, ya que sugieren que el escepticismo jurídico y garantías procesales como los interrogatorios cruzados, los expertos de la defensa, las directrices judiciales y las apelaciones, son incapaces de identificar, exponer o transmitir los problemas epistemológicos de la prueba de huellas dactilares. Incluso, permiten sugerir que los criterios jurídicos y similares para regular su admisibilidad y ayudar a la valoración de la expertise, pueden ser engañosos, mal utilizados o incluso ambos $^{6}$. Por otra parte, los desafíos jurídicos (no epistemológicos) no han permitido a los abogados y jueces reconocer las debilidades de los procesos judiciales y las garantías procesales.

Como se verá, el método comparado resulta una herramienta poderosa para estudiar la regulación de la prueba dactilar latente. Con independencia de las reglas específicas y los procedimientos en uso en un determinado tiempo y lugar, nos encontramos con resultados sustancialmente similares en casi todos los casos que componen esta muestra ${ }^{7}$. Las respuestas jurídicas son sorprendentemente consistentes. La comparación también sugiere que en los Estados Unidos (pese a sus diversos problemas, uno de los importantes constituido por los recursos con que cuenta la defensa) parecen operar sistemas jurídicos abiertos a desafíos interesantes, aun cuando sus tribunales no estén particularmente dispuestos a la intervención ${ }^{8}$. Si hay otras jurisdicciones que están respondiendo a los problemas de las pruebas de huellas dactilares latente, sus reacciones son difíciles de discernir o han sido informales. Es más que obvio el valor que dichas «respuestas» para la comprensión y la rendición de cuentas sobre este tema.

\subsection{Algunas advertencias}

He seleccionado la comparación de huellas dactilares latentes por diversos motivos. Primero, siendo uno de los primeros procedimientos científico forenses, cuenta con una extensa historia jurídica que data desde principios del siglo xx en la mayoría de las jurisdicciones que analiza este trabajo ${ }^{9}$. Esta historia prominente permite observar cómo los tribunales han abordado la prueba dactilar a lo largo de un siglo, entre 1909 y 2018. Las respuestas jurídicas a la prueba dactilar son esclarecedoras, pues hasta hace poco la validez y la fiabilidad científica de la huella dactilar como medio para la identificación de un sujeto era incierta ${ }^{10}$.

Segundo, la comparación de huellas dactilares es algo así como un caso difícil. No es mi argumento explícito que la prueba dactilar sea una ciencia débil o ciencia basura. Al contrario, los nuevos estudios científicos vienen a reforzar las impresionantes (incluso extraordinarias) habilidades que tienen los peritos dactilares capacitados y

\footnotetext{
6 Martire y Edmond, 2017. 41

EDMOND et al, 2013.

Giannelli, 200489.

9 Sengoopta, 2003.

10 Es decir, no conocida.
} 
experimentados ${ }^{11}$. Esto significa que este trabajo se centra en (lo que ahora se sabe que es) un procedimiento demostrablemente válido. Sin embargo, este estatus solo se ha conseguido en la última década, cuando los científicos investigadores llevaron a cabo los primeros estudios de "caja negra» para medir el desempeño de los examinadores dactilares bajo condiciones controladas ${ }^{12}$. Los resultados de estos estudios, especialmente la incidencia del error, junto con la continua indiferencia de los examinadores a factores humanos (como los sesgos cognitivos) indican que la respuesta jurídica histórica a las pruebas dactilares no ha estado científicamente fundada ${ }^{13}$. Los decisores eran efectivamente ignorantes. Las decisiones estaban basadas en percepciones populares, en las afirmaciones de los examinadores dactilográficos y sus organizaciones y en las prácticas y experiencia jurídicas convencionales. En definitiva, este análisis sobre la prueba dactilar nos permite explorar la respuesta jurídica a un tipo de prueba pericial cuyo valor probatorio durante la mayor parte de su historia ha sido incierto. Esta es una historia de un éxito sutil y cualificado.

En tercer lugar, este trabajo está preocupado fundamentalmente por cuestiones epistemológicas. Es decir, por la investigación científica y los retos metodológicamente sofisticados que centran la atención en la validez, la fiabilidad científica, los estándares, la incertidumbre, el error y los sesgos $\operatorname{cognnitivos}^{14}$. Se enfoca en los métodos (y los presupuestos) y el valor conocido de la prueba dactilar, no en aspectos específicos de casos individuales (y si las decisiones sobre coincidencias dactilares fueron correctas en cada caso) ${ }^{15}$. Como veremos, históricamente hay pocas impugnaciones sobre la admisibilidad y el uso de la prueba dactilar relacionadas con estos temas fundamentales. Durante todo el siglo xx, los retos para la prueba dactilar fueron jurídicos más que epistemológicos. Salvando pocas excepciones, se discutían criterios jurídicos y formas argumentativas. Eran formalistas y técnicos ${ }^{16}$. Si bien no hay nada novedoso en que los abogados y los jueces se impliquen con la legislación, las categorías y criterios jurídicos y la jurisprudencia, su persistente insensibilidad al conocimiento científico es una cuestión que exige nuestra atención.

Finalmente, este trabajo es especulativo. Está concebido ambiciosamente. Solo ofrece bocetos sugerentes de desarrollos sociales e institucionales relacionados e incluye ciertas lagunas. Sin embargo, al intentar entender algunas de nuestras prácticas de forma diacrónica, comparada (tanto con otras jurisdicciones como con otras áreas de conocimiento, como son las ciencias tradicionales) y empírica, nos da luces sobre asunciones, actitudes y prácticas jurídicas complacientes. Nos sugiere que podríamos estar en una mejor situación dados los recursos y conocimientos actualmente dispo-

11 Véase e.g. Tangen, Thompson y McCarthy, 2011 y Ulery, et. al., 2011.

12 Donde la respuesta correcta es conocida previamente, a diferencia de los casos estudiados.

13 Dror, 2006.

14 Véase e.g. Erica Beecher-Monas, 2007; Saks y Spellman, 2016; Martire y Edmond, 2017.

15 En la gran mayoría de los casos no sabemos ni podemos saber si la decisión es correcta, así que dichas creencias - incluso si son verificadas - no constituyen una validación. Véase en general FAIGMAN, Monahan y Slobogin, 2014.

16 Véase Jasanoff, 1995. 
nibles para las instituciones jurídicas y los decisores; y, a la vez, refuerza el legado de prácticas y compromisos pasados que, no obstante, son (in)justificables. Aunque esté enfocado en la prueba dactilar latente en las jurisdicciones adversariales más importantes (y en Australia), este trabajo podría también contribuir a la comprensión de la respuesta jurídica a otros tipos de ciencias forenses y al uso de la prueba científicoforense en otras jurisdicciones del common law (y más allá) ${ }^{17}$.

\section{RECONOCIMIENTO: ADMISIÓN Y USO TEMPRANO, DESDE 1909 A 1923 (EN CANADÁ, NO OBSTANTE, HASTA 1946)}

Esta sección presenta las primeras decisiones reportadas con prueba de huellas dactilares latentes en cada una de nuestras jurisdicciones. De esta manera, documenta el reconocimiento jurídico de la "ciencia de las huellas dactilares» ${ }^{18}$. Estos casos (en su mayoría apelaciones) no son necesariamente las primeras ocasiones en que se utilizaron pruebas de huellas dactilares para ayudar con la identificación de sujetos en investigaciones y procedimientos penales en nuestras jurisdicciones. Más bien, estos casos representan las primeras ocasiones en las que se cuestionó algún aspecto de la prueba dactilar, a menudo en apelaciones, como que un tribunal de primera instancia y/o de apelación consideró la admisibilidad o, como es más común, algún aspecto probatorio (por ejemplo, si una sola huella dactilar puede constituir prueba más allá de toda duda razonable). Estos son los primeros casos reportados y tienen variaciones. Incluyen cuestiones como si la prueba debe ser tratada como un hecho o como una opinión*, o si el juzgador de los hechos puede comparar las impresiones de las huellas por sí mismo. En Australia un tribunal cuestionó las afirmaciones sobre la «unicidad» de los peritos de huellas dactilares y los jueces canadienses demostraron, al menos, una renuencia ocasional a admitir o usar en su decisión pruebas dactilares, incluso cuando el caso en general podría considerarse convincente (visto hoy en día). En cada jurisdicción se sostiene la admisibilidad de las pruebas dactilares y en la mayoría de las decisiones su valor probatorio se supone o se considera abrumador. Con la excepción temporal de Canadá, ninguno de los tribunales cuestiona o califica la identificación positiva alcanzada con pruebas dactilares usando huellas latentes.

17 Los lectores interesados en tener una visión general de la comparación de huellas dactilares latentes, pueden consultar el informe de la AAAS (2017), Apéndice B. Disponible en: https://mcmprodaaas. s3.amazonaws.com/s3fs-public/reports/Latent\%20Fingerprint\%20Report\%20FINAL\%20914.pdf?i9 xGSEyMHnIPLG6INIUyZb66L5cLdlb

Thompson, et al, 2017) ('AAAS report').

18 Esta y variaciones similares son comunes y frecuentes en Galton's Fingerprints (1892) y en las distintas ediciones de FBI, The Science of fingerprints: Classification and uses (2013).

* Nota de traducción: Hay una regla general en el common law que establece que quien ofrece un testimonio solo puede decir lo que vio y no hacer inferencias a partir de ello o decir lo que piensa u opina. Cuando se tata, en cambio, de un testimonio experto, el perito sí puede hacer inferencias y/o dar su opinión al respecto. Por ello, a esta última se le identifica también como «opinion evidence», al igual que a algunas excepciones a la regla general para los testigos oculares. 


\subsection{Inglaterra y Gales: $R v$. Castleton (1909) y $R v$. Bacon (1916)}

Las huellas dactilares fueron tempranamente utilizadas en investigaciones en Inglaterra desde $1902^{19}$. Se utilizaron para condenar a Harry Jackson por el robo de bolas de billar, donde la defensa cuestionó la perdurabilidad de las huellas dactilares, pero no su unicidad. Cole documenta las impugnaciones de la defensa en 1903 y 1905. Sin embargo, la primera impugnación inglesa seria parece haber ocurrido en el «juicio por asesinato de Deptford», donde «once crestas características coincidentes» fueron identificadas con Alfred Stratton, implicando a los hermanos Stratton en el caso. La defensa de los Stratton fue excepcional. Contrataron como peritos a John Garson, ex jefe de la Oficina de Antropometría de la Scotland Yard en la década de 1890, y a Henry Faulds, «uno de los pioneros del sistema británico de identificación mediante huellas dactilares» ${ }^{20}$. Los hermanos fueron declarados culpables y sentenciados a la horca, a pesar de las dudas del juez del juicio sobre las pruebas de huellas dactilares. Después del juicio, Faulds publicó una crítica sobre el «uso erróneo» de este nuevo y poderoso procedimiento en su Guide to Finger-print Identification (1905). Allí, expresó su preocupación por el creciente uso de la comparación de huellas dactilares por parte de la policía: «funcionarios subordinados sin capacitación en la observación científica» e institucionalmente susceptibles a sesgos ${ }^{21}$.

El primer caso reportado en nuestra muestra, y citado posteriormente por el resto de todas nuestras jurisdicciones, es el caso inglés $R v$. Castleton ${ }^{22}$. Castleton no discute sobre la admisibilidad de la prueba, sino más bien si una huella dactilar por sí sola puede ser suficiente para fundar una condena penal. Una vela que supuestamente tenía la huella de Castleton incrustada en la cera se encontró en la escena de un robo. El abogado de Castleton sugiere que la huella dactilar podría haber sido colocada allí por otra persona ${ }^{23}$. En uno de los pocos intercambios registrados, uno de los jueces de apelación preguntó: «iPuede el prisionero encontrar a alguien cuyas huellas dactilares sean exactamente iguales a las suyas?» ${ }^{24}$. En un fallo extraordinariamente breve (reproducido en su totalidad a continuación), el Juez Presidente desestimó la apelación en nombre de la Corte de Apelaciones en asuntos penales:

Somos de la opinión de que esta solicitud debe ser evidentemente desestimada. Se ha sugerido que otra persona podría haber colocado estas huellas dactilares, pero esa sugerencia fue presenta-

19 Usos jurídicos tempranos fueron registrados en 1892 en Argentina (caso Rojas), Francia en 1902 (Scheffer) y en India en 1905 (Emperor v. Abdul Hamid, 32 Indian Law Reports 759).

20 Discutido en Cole, 2001.

21 FAuld, Guide to Finger-print Identification, iii-v.

22 Podemos notar que esta decisión sigue lo señalado en The Report of the Commissioners on FingerPrints.

23 Uno podría preguntarse si es que más que las huellas dactilares, en realidad la vela pudo haber sido "colocada por alguien más». En Parker v. The King (1912) 14 CLR 681, 156, el juez de Victoria se preguntaba si es que Castleton "pudo haberla llevado [la vela] a otro lugar, y después algún ladrón la llevó a la casa robada donde fue encontrada».

24 En Parker, 155, el juez de Victoria se excusó, señalando que esta pregunta «no pudo haberse hecho seriamente». 
da ante el jurado, que decidió sobre las pruebas que tenían ante ellos. Nuestra atención ha sido dirigida a las fotografías de las impresiones de las huellas dactilares. Observando el dedo medio en particular, así como el índice de la mano derecha, estamos de acuerdo con la prueba presentada por el experto en el juicio oral ${ }^{25}$.

Afirmando implícitamente su admisibilidad, el Tribunal defirió en el jurado la cuestión de la transferencia y confirmó el veredicto de culpabilidad y el valor probatorio de la prueba, basándose en cierta medida en su propia evaluación de las huellas dactilares.

Para 1909, en Inglaterra y Gales ya era admisible la prueba de huellas dactilares latentes para demostrar la identidad e incluso la culpabilidad de un sujeto. Apenas unos años más tarde, en un caso en que se discutía la condición del prisionero como un «delincuente habitual», el Tribunal en $R v$. Bacon aceptó la prueba ofrecida por un analista de huellas dactilares que señalaba que otros ocho delitos vinculados a nombres diferentes, pero con huellas dactilares similares fueron en realidad el trabajo de un solo hombre ${ }^{26}$. Después de Castleton (y Bacon), el interés jurídico inglés se trasladó a cuestiones más bien procesales, junto con cierto interés por la cantidad de puntos de coincidencia necesarios para identificar positivamente a una persona, como se analizará a continuación.

\subsection{Estados Unidos: People v. Jennings (1911) y State v. Cerciello (1914)}

People v. Jennings es el primer caso reportado sobre huellas dactilares en Estados Unidos ${ }^{27}$. La prueba dactilar jugó un papel fundamental en un caso que de otra manera habría sido simplemente una sólida acusación basada en pruebas circunstanciales. En la apelación, Jennings cuestionó la admisibilidad de la identificación por comparación de huellas dactilares latentes. Fue declarado culpable de asesinato, en un caso de robo donde el propietario de la vivienda fue asesinado a tiros durante una escaramuza con el intruso. Jennings fue arrestado esa noche poco después de los hechos. Fue vinculado a otros asaltos en la zona perpetrados esa misma noche y fue detenido en posesión de un arma de fuego y balas. Las balas eran de la misma marca y calibre que varias balas encontradas en la escena del tiroteo. Además, restos encontrados en los zapatos de Jennings calzaban con arena y gravilla encontradas al lado de una cama de la casa. Cuando fue arrestado, Jennings estaba herido y el bolsillo de su chaqueta roto. Durante un intento de robo en otra casa en el vecindario más temprano esa misma noche, el dueño había frustrado el asalto y en el forcejeo le rasgó el bolsillo de la chaqueta. Además, el relato de Jennings sobre lo que habría hecho esa noche era improbable e inconsistente con el testimonio recogido de aquellos a quienes supuestamente había visitado.

$25 R v$. Castleton [1909] 3 Cr App R 74. Podría haber habido más de una huella dactilar que calzaba.

26 R. v. Bacon (1915) 11 Cr App R 90.

27 People v. Jennings, 252 III. 534, 96 N.E. 1077 (1911). 
Entonces vino la prueba dactilar. Las huellas de cuatro dedos de una mano izquierda fueron recuperadas de una barandilla adyacente al supuesto punto de entrada en la casa donde ocurrió el homicidio ${ }^{28}$. Encontradas en pintura aún húmeda, las huellas fueron fotografiadas y comparadas con las impresiones dactilares de Jennings ${ }^{29}$. Cuatro analistas de huellas dactilares (incluida una mujer y un miembro de la Real Policía Montada de Canadá, ambos capacitados por la Scotland Yard) declararon que las huellas coincidían.

Todos estos testigos expertos declararon en mayor o menor medida sobre el sistema de reconocimiento por huellas dactilares y las diversas marcas que se pueden encontrar en la mano humana, indicando que se han clasificado según las diversas formas de las marcas, incluidas las conocidas como «arcos», «anillos», «espirales» $\mathrm{y}$ «deltas». ${ }^{30}$

Dos de los testigos reportaron 14 puntos de coincidencia entre las huellas.

Al revisar la admisibilidad de las pruebas de huellas dactilares, la Corte Suprema de Illinois reconoció el «carácter incierto» de muchas pruebas de identificación ${ }^{31}$. La Corte explicó que las identificaciones mediante testigos oculares y por voz eran admisibles ${ }^{32}$. En cuanto a las fotografías de las huellas dactilares, para hacer la comparación, no había «ninguna duda" de «la exactitud de la prueba fotográfica» ${ }^{33}$. En cuanto a la admisibilidad de las imágenes, la Corte explicó que las fotografías y los rayos X habían sido inicialmente cuestionados, pero ahora son "admitidos sin duda ${ }^{34}$. La Corte no pudo encontrar ninguna autoridad de los EE. UU. que se hubiese pronunciado sobre la admisibilidad de las pruebas dactilares latentes, pero aceptó que «las autoridades estándar sobre temas científicos que han discutido el uso de las huellas dactilares como un sistema de identificación, concluyen que la experiencia ha demostrado que es fiable» ${ }^{35}$. Esto se sustenta refiriendo al "origen antiguo" de este «sistema de identificación» y a su uso en los tribunales de la India, «varios países europeos'" $\mathrm{y}$ "en Inglaterra ... desde 1891 en miles de casos sin erron ${ }^{36}$.

La Corte no solo estaba conforme, sino que además indicó que «no se puede negar que se conozcan judicialmente» pruebas de huellas dactilares latentes.

Estamos inclinados a sostener con base en la prueba de los cuatro testigos expertos que declararon y de los escritos a los que nos hemos referido sobre este tema, que existe una base científica para el sistema de identificación de huellas dactilares y que los tribunales están justificados para admitir

${ }^{28}$ Hacer una correspondencia con múltiples huellas dactilares con diferentes dedos de la misma persona disminuye considerablemente las posibilidades de error.

29 Los primeros casos consistían generalmente en comparar las huellas de un sospechoso específico, en este caso Jennings, más que en buscar y comparar en algún registro público.

30 Jennings, 1082.

31 Jennings, 1081, en referencia al infame caso Tichborne en Inglaterra.

32 Sin embargo, esta es prueba directa (i.e. sensorial).

33 Jennings, 1081.

34 Jennings, 1082. Más adelante se discutieron temas relacionados, Véase e.g. U.S. v. Buck, 1987 WL 19300.

35 Jennings, 1081 (cursiva añadida).

36 Jennings, 1081 (cursiva añadida). El uso europeo incluso llevó a que las agencias gubernamentales estadounidenses lo investigaran y posteriormente adoptaran. 
este tipo de prueba; que este método de identificación tiene un uso tan común que los tribunales no pueden negarse tenerlo en cuenta.

...El testimonio de un experto es admisible cuando el objeto de la investigación es de tal carácter que solo las personas con habilidades y experiencia en él son capaces de formarse un juicio correcto sobre cualquier hecho relacionado con el $\mathrm{mismo}^{37}$.

La Corte consideró que «la clasificación de las impresiones de huellas dactilares y su método de identificación es una ciencia que requiere estudio» ${ }^{38}$. El jurado no estaba en posición de considerar las pruebas dactilares sin la ayuda de «testigos con experiencia particular y especial sobre este tema» ${ }^{39}$. La Corte consideró que la prueba pericial cumplía con el estándar de admisibilidad vigente y que los cuatro expertos en huellas dactilares estaban lo suficientemente calificados para declarar. En ese sentido, la Corte refiriéndose a Castleton se mostró consistente con la posición de Gran Bretaña, donde «las huellas dactilares podrían ser admitidas como prueba» ${ }^{40}$.

Sobre la cuestión de si los testigos podían declarar como un hecho que las huellas dactilares encontradas eran efectivamente de Jennings o si debía considerarse solamente como una opinión, el Tribunal concluyó que si bien:

es habitual que los testigos expertos declaren lo que creen o piensan, o si según su criterio tal cosa es cierta o no, no existe ninguna norma que les impida declarar sobre dichos temas. Corresponde al jurado determinar el peso que se le dará a su testimonio ${ }^{41}$.

Jennings fue posteriormente ejecutado.

Al igual que en Inglaterra, la prueba dactilar parece haber sido presentada y ocasionalmente cuestionada en procedimientos que pasaron inadvertidos en los reportes publicados ${ }^{42}$. Otra acusación contemporánea a Jennings ocurrió en State v. Crispi en $1911^{43}$. Este fue un caso por robo en el que se recuperó una huella dactilar de un panel de vidrio ${ }^{44}$. En Crispi, el juez (un tanto escéptico), el acusado y la mayoría de los miembros del jurado, fueron aparentemente persuadidos por una demostración en vivo ante ellos, donde el examinador de huellas dactilares realizó una compara-

37 Jennings, 1082 (cursiva añadida). Esto suena como una forma temprana de declaración de hechos notorios. Véase también State v. Cerciello, 90 A. 1112, 1114 (N.J. 1914) donde los argumentos de la apelación versaban principalmente sobre la lupa usada por el jurado y la manera en que las huellas dactilares del acusado fueron obtenidas (para compararlas con aquellas encontradas en el arma homicida). Respecto al criterio de admisibilidad y la necesidad de dejar la calificación de la opinión experta al jurado, la Corte explicó que no podía «ignorar» las «tendencias científicas y progresistas de la época».

38 Jennings, 1083 (cursiva ańadida).

39 Jennings, 1083 (cursiva ańadida).

40 Jennings, 1081.

41 Jennings, 1083.

42 Estos juicios en los EE. UU, Inglaterra y otros lados fueron cubiertos de manera irregular por la prensa, incluyendo a veces detalles relevantes de los casos.

43 Discutido en Cole, 2001: 181-185. Se buscaron ladrones conocidos en los registros de huellas dactilares existentes para compararlos con la huella dactilar latente encontrada en el panel de vidrio de la casa allanada.

44 La defensa cuestionó la necesidad de un testigo experto para interpretar las huellas dactilares. 
ción e identificó una huella dactilar con una muestra de uno de los 12 jurados ${ }^{45}$. En respuesta a la prueba dactilar (y la demostración realizada por el experto), el acusado se declaró culpable y, por lo tanto, no hubo revisión de la decisión de admisibilidad o de la condena ${ }^{46}$.

Las próximas referencias a pruebas dactilares las encontramos en Nueva Jersey. Las huellas dactilares latentes fueron parte de un caso en contra de un recolector de basura acusado de violación en State v. De Geralmo ${ }^{47}$. Ni la admisibilidad ni el valor probatorio de las huellas dactilares recuperadas y que calzaban con De Geralmo fueron cuestionadas. La apelación ante la Corte Suprema fue confirmada por la insatisfactoria manera en que la coartada del acusado se sometió al jurado, en términos de prueba suficiente y duda razonable. La segunda impugnación relevante reportada en Estados Unidos ocurre en State v. Cerciello ${ }^{48}$.

Cerciello fue declarado culpable de matar a su joven esposa con un hacha. El caso en su contra fue circunstancial, basado en huellas de zapato encontradas en el suelo adyacente al cuerpo, un botón (parecido a uno que faltaba en la ropa de Cerciello) encontrado cerca del cuerpo, declaraciones de intención (que involucran un hacha), confesiones hechas a otros prisioneros después de su detención, junto con huellas dactilares latentes en sangre encontradas en el hacha recuperada de la escena del crimen. El motivo fue la supuesta infidelidad de la esposa. Cerciello apeló cuestionando la admisibilidad de las pruebas de huellas dactilares latentes y la entrega de lupas a los jurados. Las lupas fueron utilizadas por el examinador de huellas dactilares «en el juicio oral para ayudar a detectar lo que supuestamente era la impresión de las huellas dactilares del acusado en el hacha». Aunque las lupas supuestamente eran más poderosas que las utilizadas por el público en general la Corte "no pudo entender cómo su admisión lo perjudicó» ${ }^{49}$.

La comparación y la identificación de las huellas dactilares fue impugnada de dos maneras. El acusado impugnó la admisibilidad de la prueba dactilar y, como presagiando muchas futuras discusiones, cuestionó las circunstancias en que se obtuvieron las impresiones de huellas del sospechoso. A falta de una legislación sobre el tema y no obstante existir reglas contra la provisión involuntaria de pruebas (lo que lo convierte en «un testigo contra su voluntad»), la Corte consideró que era aceptable haber obtenido subrepticiamente las huellas dactilares del prisionero, habiéndolo hecho firmar un documento.

45 Cabe señalar que la demostración ante el tribunal, que atribuye una huella dactilar específica a uno de los doce posibles candidatos del jurado, no es un apoyo particularmente convincente para las reclamaciones sobre unicidad o identificación positiva con la exclusión de todas las demás personas.

${ }^{46}$ Quizás, al igual que en muchos de los primeros casos en los que se utilizaron detectores de mentiras, la prueba dactilar puede haber fomentado confesiones de culpabilidad. Véase Alder, 2007 y Bunn, 2012.

47 State v. De Geralmo, 82 Atlantic Rep. 643 (1912).

48 State v. Cerciello, 90 Atlantic Rep. 1112 (1914).

49 Cerciello, 1114. 
De una revisión de la declaración, no consideramos que se haya violado dicha garantía procesal... Lo que hizo en el momento en que se sometió a pedido de los oficiales. La escritura de la carta que resultó en la impresión de sus huellas dactilares fue a nuestro juicio voluntaria de su parte, ya que obviamente no se utilizaron amenazas para obligarlo a hacerlo ${ }^{50}$.

En cuanto a su admisibilidad, si bien la identificación por huella digital «no es totalmente res nova en principio, en su aplicación práctica en el procedimiento penal en esta jurisdicción es esencialmente novel» ${ }^{51}$. La Corte explicó la admisibilidad de las pruebas de huellas dactilares en los siguientes términos «progresistas»:

\begin{abstract}
En principio, su admisión como prueba jurídica se basa en la teoría de que la evolución en los asuntos prácticos de la vida, según la cual las tendencias progresistas y científicas de la era se manifiestan en todas las demás actividades humanas, no puede ser ignorada por el proceso judicial, así el ordenamiento jurídico en sus esfuerzos por hacer cumplir la justicia mediante la demostración de un hecho en cuestión, permitirá la prueba de aquellos procesos científicos que sean el trabajo de hombres educados y hábiles en sus respectivas actividades y los aplicará a la demostración de un hecho, dejando enteramente a la consideración del jurado el peso y los efectos que se le dará al esfuerzo y sus resultados. ... Los ejemplos son numerosos y los libros están repletos de casos en los que esta regla, surgida y aplicada ex necessitate, y basada insipientemente en la máxima del derecho civil "cuilibet in sua arte perito est credendum», que exhibe una de las reglas generales de la prueba, ha sido aplicada en una variedad de casos, desde la época más temprana reportada de la common law, para dilucidar y demostrar hechos controvertidos y elusivos ${ }^{52}$.
\end{abstract}

En favor de su admisión, la Corte se refirió a la admisibilidad de la opinión de un especialista en grabados de sellos sobre «si una impresión fue tomada a partir de un sello original o de una impresión», de la opinión de "un experto en caligrafía» e incluso de la admisión de impresiones fotográficas. También observó que los tribunales habían permitido previamente testimonios sobre el parecido coincidente de una huella sangrienta de la mano de un acusado y «una comparación entre el tamaño y la forma de los zapatos y las huellas de un acusado hallados cerca de la escena de un asesinato" ${ }^{53}$. La prueba dactilar, así como experiencia de los examinadores fue declarada admisible. Sin embargo, la Corte dejó a la determinación del jurado el "peso del ... testimonio y su importancia como prueba en el caso» ${ }^{54}$.

Poco después de estos casos, en 1923, un tribunal federal dictó lo que a menudo se describe como un importante criterio de admisibilidad para la prueba pericial, en un caso relacionado con un primitivo detector de mentiras. Al excluir esta prueba en Frye v. EE. UU. (1923), el Tribunal de Apelaciones de D.C. adoptó el siguiente criterio:

Es difícil de determinar el momento exacto en que un principio o descubrimiento científico cruza la línea entre su etapa experimental y la ya demostrable. En algún punto de esta zona gris se debe reconocer el valor probatorio de este principio o descubrimiento, y si bien los tribunales

50 Cerciello, 1115.

51 Cerciello, 1114.

52 Cerciello, 1114.

53 State v. Miller, 60 Atl. 202 (1905); State v. Morris, 84 N.C. 756 (1881) (no se necesitó ningún experto para comparar las huellas de zapatos en el suelo).

54 Cerciello, 1114. 
admitirán el testimonio de expertos sobre un descubrimiento o principio científico bien reconocido, el asunto a partir de la cual se hace la deducción debe estar suficientemente establecido y haber ganado la aceptación general en el área particular a la que pertenece ${ }^{55}$.

Curiosamente, no hay impugnaciones de admisibilidad asociadas con la introducción del criterio de la «aceptación general» para las pruebas de huellas dactilares latentes hasta finales de los años sesenta ${ }^{56}$.

\subsection{Australia: Rex v. Blacker (1910) y R. v. Parker (1912)}

Los dos primeros casos reportados en Australia, uno en cada uno de los estados más poblados, ilustran lo temprano que se movió el foco principal más allá de la admisibilidad del uso de fotografías y si una huella dactilar por sí sola podría ser prueba suficiente para identificar a una persona más allá de toda duda razonable. Al igual que en Inglaterra y Gales, en tan solo unos pocos ańos la admisibilidad de las pruebas de huellas dactilares latentes parece haberse dado por sentada; solo algunos de los procedimientos y prácticas asociadas a la prueba dactilar generaron impugnaciones ocasionales abordadas en las decisiones reportadas.

El caso en $R . v$. Blacker trata sobre un asalto sufrido por un jardinero de un mercado chino, en el que le saquearon su cabaña y le robaron dinero en efectivo de una caja. Una huella dactilar latente encontrada en la caja fue comparada con el pulgar de Blacker. Usando una "poderosa lupa» el subinspector de policía Childs identificó 14 puntos de similitud entre las muestras y concluyó que la impresión dactilar en la caja había sido hecha por el pulgar de Blacker ${ }^{57}$. Blacker fue condenado. La discusión promovida en este caso fue si las fotografías ampliadas de las huellas dactilares latentes y de las impresiones tomadas a Blacker eran admisibles. La defensa cuestionó la admisibilidad de las ampliaciones de las imágenes, ya que ninguna de las imágenes ampliadas capturaba del «todo» las huellas ni la latente ni la muestra de Blacker. Más

55 Frye v. U.S., 293 F. 1013 (D.C. 1923).

56 El primer tribunal federal en considerar la prueba dactilar con el criterio Frye (en los reportes de Westlaw) es People v. King, 266 Cal.App.2d 437 (1968). Véase también Reed v. State, 283 Md. 374 (1978); State v. Lawshea, 798 S.W.2d 198 (1990); Wilson v. State, 574 So.2d 1324 (1990); Com. v. Ghee, 414 Mass. 313 (1993). No hay casos reportados de decisiones federales pre-FRE (i.e. pre-1975) que consideren la admisibilidad de la prueba dactilar conforme al estándar Frye. Sin embargo, véase U.S. v. Piccinonna, 885 F.2d 1529 (11th Cir. 1989): "En general, no se ha confiado en el estándar Frye para la admisión de pruebas tales como huellas dactilares, balística, toxicológicas ni radiografías» y Cain v. United States, 2017 WL 3840258: "A los expertos en huellas dactilares se les ha permitido habitualmente declarar en este distrito. El Cuarto Circuito ha dicho: «Si bien los principios que subyacen a la identificación de huellas dactilares no han alcanzado el estatus de ley científica, aun así tienen el sello de una fuerte aceptación general, no solo en la comunidad de expertos, sino también en los tribunales». United States v. Crisp, 324 F.3d 261, 268 (4th Cir. 2003) (casos citados). De hecho, el Cuarto Circuito ha reconocido que "prácticamente todos los Circuitos y tribunales de distrito, tanto antes como después de Daubert, tienen una larga tradición de permitir que los examinadores de huellas dactilares expresen sus opiniones y conclusiones, sujeto a un riguroso interrogatorio cruzado».

57 R. v. Blacker [1910] SR (NSW) 357, 358. 
bien, la ampliación se centraba exclusivamente en la parte específica utilizada para la comparación. Las fotografías de las impresiones completas, no ampliadas, se admitieron junto con las ampliaciones parciales.

En cuanto a las pruebas de huellas dactilares, el Magistrado Presidente de Nueva Gales del Sur no tenía dudas respecto su admisibilidad ${ }^{58}$.

Esta nueva ciencia de identificación por huellas dactilares se basa en experimentos que muestran que la parte del cuerpo con mayor probabilidad de permitir la identificación de una persona sin probabilidad de error es la parte bulbosa del pulgar, y si se encuentra que existe similitud, la prueba es muy confiable. En el presente caso, la prueba ofrecida por el experto mostró que la similitud era lo suficientemente fuerte como para justificar la admisión de la prueba sobre el punto ${ }^{59}$.

$\mathrm{Al}$ igual que el jurado, el Magistrado Presidente y sus colegas consideraban que las huellas dactilares habían sido hechas por la misma persona.

En relación con las ampliaciones parciales, la Corte aceptó que «todas las marcas en las que se basaron las pruebas para la identificación fueron presentadas» ${ }^{60}$. Las ampliaciones fueron necesarias «para ilustrar y explicar lo que de otra manera el jurado no podría ver por sí mismo» y para permitir que «la prueba ofrecida por el experto ... fuera comprobada ${ }^{61}$. La omisión de algunas marcas circundantes, aparentemente borrosas y que no fueron utilizadas para realizar la comparación, era jurídicamente irrelevante ya que el acusado no pudo demostrar que la porción utilizada «era insuficiente» ${ }^{62}$. El Magistrado Presidente insistió en que la prueba dactilar «fue cuidadosamente ofrecida y debidamente comprobada». En particular, el jurado fue «cuidadosamente advertido por el experimentado juez en cuanto al riesgo de error al que es susceptible esta clase de pruebas» $\mathrm{y}$ «se tomaron todas las precauciones para evitar que se trasmitiera cualquier impresión errónea al jurado» ${ }^{63}$.

$\mathrm{Al}$ igual que el caso Jennings en EE. UU, $R$. v. Parker generó una apelación más detallada respecto a algunas de las cuestiones relacionadas con la introducción de pruebas dactilares. Parker es otro caso que no se enfoca directamente en la admisibilidad de las pruebas de identificación. La apelación de Parker fue sobre el valor de la prueba, sus riesgos y la suficiencia de una sola huella dactilar latente para probar los hechos delictivos. Parker es un caso atípico si tomamos en cuenta nuestra muestra de casos, ya que a pesar de que la mayoría de los jueces consideró que las pruebas dactilares eran admisibles y convincentes, el Magistrado Presidente de Victoria estaba en desacuerdo.

Parker fue declarado culpable de irrumpir en un almacén y robar joyas de una caja fuerte. Se obtuvo una huella dactilar latente de una botella de cerveza de jengibre

58 Blacker, 360.

59 Blacker, 360 (cursiva añadida). No se hace referencia a experimentos ni a pruebas que respalden que la parte bulbosa del pulgar sea el dato más útil para la comparación dactilar.

60 Blacker, 361.

61 Blacker, 361. Confróntese con Bennett v. Police [2005] SASC 167 (discutido supra), donde no se exige como requisito proveer imágenes o marcas del examinador.

62 Blacker, 361-2.

63 Blacker, 360. 
ubicada al lado de la caja fuerte. Tanto una fotografía de la huella latente encontrada como una fotografía del dedo medio de Parker fueron ampliadas y admitidas en juicio oral. El detective Potter, a cargo de la oficina de identificación de huellas dactilares, declaró sobre el parecido y "señaló al jurado nueve puntos de similitud», así como cicatrices que supuestamente aparecían en ambas imágenes ${ }^{64}$. Su declaración fue resumida del siguiente modo:

... él había concluido que el dedo del prisionero debió haber hecho la impresión dactilar en la botella. Había examinado decenas de miles de huellas dactilares y nunca había encontrado dos iguales. Las marcas en los dedos de una persona siguen siendo las mismas durante toda su vida. El inspector Child, de la policía de Nueva Gales del Sur, declaró en el mismo sentido. No hay dos personas con las mismas huellas dactilares ${ }^{65}$.

El inspector Childs (de Blacker) «declaró en el mismo sentido» ${ }^{66}$. El jurado lo declaró culpable, pero el abogado defensor solicitó que el Tribunal de Apelaciones considerara si el "parecido entre las huellas dactilares ... es suficiente para respaldar una condena» ${ }^{67}$. Tres jueces consideraron esta pregunta, dos decidieron que sí podía. La mayoría señaló que «no se ha sugerido que esta prueba haya sido erróneamente admitida" ${ }^{68}$. Al reflexionar sobre las pruebas dactilares, el Magistrado Hodges consideró que en términos de identificación y en comparación con la prueba de testigos oculares, las huellas dactilares:

son la prueba de identificación más sólida, más satisfactoria y más concluyente que podría producirse $y$, por lo tanto, ... una prueba de identificación mediante huellas dactilares puede ser sin duda suficiente para justificar la condena del acusado ${ }^{69}$.

\section{Continuó,}

En mi opinión quizás sea la prueba más segura de todas, dado que no depende de las impresiones causadas por un vistazo momentáneo, si no que la impresión queda registrada y el jurado puede ver y juzgar por sí mismo la comparación de las huellas dactilares, siendo el experto simplemente una ayuda para permitir que el jurado juzgue por sí mismo la prueba ${ }^{70}$.

Hodge estaba convencido de que presentar las imágenes al jurado y permitir el interrogatorio cruzado era el camino «apropiado». Debido a que no había visto ni escuchado el interrogatorio cruzado, no pudo señalar «si ... hubiese coincidido» con el resultado ${ }^{71}$. El Magistrado Cussen explicó: «parece que esto es lo que se ha establecido, que hay un grado muy alto de probabilidad de que la huella dactilar atribuida al prisionero fue hecha por su dedo" ${ }^{72}$. No había ningún requisito adicional de que

64 Parker v. The King (1912) 14 CLR 681, 682.

${ }_{65}$ R. v. Parker [1912] VR 152, 153.

66 Parker, 153.

67 Parker, 153.

68 Parker, 157.

69 Parker, 158.

70 Parker, 158.

71 Parker, 159.

72 Parker, 161. 
la prueba dactilar fuera corroborada por otra clase de pruebas, por lo que se confirmó la condena.

En su voto disidente, el Magistrado Presidente advirtió el «extremo riesgo» de permitir una condena basada únicamente en la prueba dactilar:

\begin{abstract}
El extremo peligro de llegar a tales conclusiones me obliga a no postergar mi opinión. Se nos pide que aceptemos como un hecho científico establecido la teoría de que la correspondencia entre dos grupos de huellas dactilares es una prueba concluyente de la identidad de la persona que hizo esas impresiones, sobre la misma base que la proposición de Euclides y otros asuntos científicamente avalados y universalmente aceptados como probados lo están. Si la teoría de la identificación mediante huella dactilar estuviese reconocida generalmente por los científicos sobre dicha base, no habría nada más que decir. Se dice que las marcas en los dedos de cualquier individuo conservan sus características especiales desde la cuna hasta la tumba, y también que las marcas en los dedos de dos personas nunca serán iguales, por lo que la correspondencia absoluta entre una huella dactilar y las marcas en la mano de una persona son una prueba inequívoca de que él es la persona que realizó tal impresión dactilar.

Mi dificultad surge del hecho de que el tema de las huellas dactilares no ha sido estudiado lo suficiente como para permitir que estas proposiciones sean consideradas como hechos científicos. Las huellas dactilares han sido estudiadas por el Sr. Bertillon en Francia desde un punto de vista antropométrico y por Sir Francis Galton y algunos otros, sin duda personas altamente inteligentes, desde el punto de vista de simples observadores. Pero el tema no ha sido investigado por los científicos en general como para que podamos decir que las proposiciones en que se basa la Corona son hechos científicos aceptados ${ }^{73}$.
\end{abstract}

También estaba la cuestión sobre la honestidad y la confianza. El Magistrado Presidente Madden se refirió a ser dependiente del «ipse dixit» del examinador ${ }^{74}$. ¿Cómo podría el abogado durante el interrogatorio cruzado o el jurado valorar si entre las 29.000 personas supuestamente examinadas por el experto no había «dos iguales»? ${ }^{75}$. «¿Cómo podría ser comprobada su prueba?». El Magistrado Presidente no estaba personalmente convencido de que "haya habido alguna similitud» entre la huella latente y el dedo de $\operatorname{Parker}^{76}$. Asimismo, calificó la decisión del Tribunal de Apelaciones inglés en $R . v$. Castleton como "muy insatisfactoria», señalando que no se había llamado a quienes habían comprado y entregado la cerveza de jengibre y que no se había excluido la posibilidad de que el prisionero hubiera tocado inocentemente la botella. El presidente del Tribunal pensó que el caso no debería haber sido decidido por un jurado.

A pesar de la decisión dividida en la Corte, todos los jueces estuvieron de acuerdo en que «la declaración hecha por los peritos de que no puede haber dos huellas dactilares idénticas no debió haber sido admitida porque ... su conocimiento o el conocimiento de cualquier otra persona sobre el tema no profesa estar basado en ninguna ley universal, sino que es meramente empírico» ${ }^{77}$. Es decir, estaba basado

\footnotetext{
73 Parker, 154.

74 Esta expresión se repite en Kumbo Tire Co. Ltd. v. Carmichael 526 U.S. 127 (1999).

75 Parker, 154.

76 Parker, 155.

77 Parker, Madden CJ (155), Cossens J. (159) y Hodge J. (158).
} 
en la experiencia personal. El Magistrado Cussen indicó que los examinadores de huellas dactilares podrían identificar las diferencias (con fines de exclusión), pero en lo que respecta a las similitudes, simplemente podrían señalarlas al jurado para su consideración; en ausencia de conocimiento sobre su incidencia o unicidad.

Blacker y Parker presentaron recursos de revisión ante la Corte Suprema de Australia. Ambas solicitudes fueron rechazadas sumariamente. Durante los alegatos en Blacker, el abogado planteó el tema de la ampliación de parte de la huella dactilar y la posibilidad de que «la parte omitida pudiera haber mostrado que las impresiones eran diferentes». El asunto quedó en el aire ${ }^{78}$. Al desestimar la solicitud en Parker, el Magistrado Presidente hizo una analogía entre las huellas dactilares y las firmas.

Las firmas han sido aceptadas como prueba de identidad desde que se han comenzado a utilizar. El hecho de la individualización de las corrugaciones de la piel en los dedos de la mano humana es tan generalmente reconocido en la actualidad, que requiere muy poca o ninguna prueba, aunque parece ser todavía una práctica común ofrecer peritos sobre el punto. Una huella dactilar es, por tanto, en realidad una firma infalsificable. Esto es reconocido en gran parte del mundo y en algunas partes, creo, ha sido reconocido durante muchos siglos. Sin duda, es generalmente reconocido en Inglaterra y en otros lugares de los Dominios británicos ${ }^{79}$.

Después de Blacker y Parker, las pruebas dactilares no solo eran admisibles, sino que por sí solas constituían prueba más allá de toda duda razonable. Además, la proscripción unánime de las afirmaciones sobre la unicidad de las huellas dactilares de la Corte Suprema de Victoria parece haber tenido una vida muy corta. La Corte Suprema parece haber sido satisfecha con «la individualidad de las corrugaciones de la piel en los dedos» ${ }^{80}$.

\subsection{Canadá: una aberración temporal (hasta $R . v$. Buckingham)}

Las decisiones reportadas de Canadá aparecen más tarde que en las otras jurisdicciones analizadas. La RCMP participó en la comparación de huellas dactilares latentes desde las primeras décadas del siglo xx, como confirma la aparición de un oficial de la RCMP al otro lado de la frontera en People v. Jennings. De hecho, la temprana legislación canadiense se refiere al Sistema de Señalización de Bertillon y la recopilación y comparación de huellas dactilares fue autorizada a partir de $1908^{81}$. Sin embargo, las decisiones reportadas comienzan apenas en la década de 1930 y en tales decisiones se puede observar que hasta el final de la Segunda Guerra Mundial los jueces canadienses (al menos ocasionalmente) fueron más cautelosos respecto las pruebas dactilares que los tribunales de las otras jurisdicciones analizadas.

78 Blacker v. The King (1910) 10 CLR 604, 606

79 Parker $v$. The King (1912) 14 CLR 681, 683.

80 Parker, 683.

81 Identification of Criminals Act, RSC, 1927, cap. 38. Discutido en $R v$. De'Georgio and Servello [1934] 3 WWR 374, [16]-[17]. 
Entre los primeros casos reportados encontramos $R$. v. DéGeorgio y Servello, donde el juez desestimó una acusación por el allanamiento a una tienda durante la noche, que se basaba principalmente en pruebas de huellas dactilares latentes ${ }^{82}$. El caso contra los acusados fue circunstancial. Aparte de la huella dactilar latente recuperada desde el interior de la tienda, la policía decía haber observado a De’Georgio y Servello "vagando por la ciudad ... aparentemente sin rumbo", sangre en la caja registradora, un corte en el dedo de Servello y la presencia de una supuesta «llave maestra» encontrada en la casa ocupada por los acusados. No se aportaron pruebas sobre si la llave era en realidad una llave maestra, si la mancha en el cajón era en realidad sangre ni sobre la antigüedad de la herida de Servello. El juez del juicio, tras haber concluido que la prueba circunstancial no podía establecer la culpa de los acusados, no consideró las huellas dactilares latentes.

Las citas de las decisiones reportadas las encontramos en Kuhne, Identification and Classification of Fingerprints (1921), adoptadas por la Corona ${ }^{83}$. El extracto se refiere a la importancia de persuadir al jurado de que «el testimonio de los expertos en huellas dactilares es una prueba idónea, fiable y concluyente». Kuhne insiste en la superioridad de la comparación de huellas dactilares sobre las pruebas caligráficas. El extracto enumera tres supuestas ventajas sobre la caligrafía: (i) «las impresiones ... no pueden ser disimuladas, falsificadas o alteradas»; (ii) los expertos en huellas dactilares pueden hacer una identificación positiva casi instantáneamente, sin dudarlo; y (iii) el «testimonio de un experto en huellas dactilares no está sujeto a la contradicción de otro experto en huellas dactilares» ${ }^{84}$. El fiscal presentó la prueba ofrecida por el examinador de huellas dactilares «no [como] una mera opinión, sino como un hecho concluyente». El juez rechazó dicho análisis:

Creo que el derecho se mueve de forma lenta pero segura, y nunca he oído decir que la identificación por huellas dactilares se haya convertido en una ciencia tan bien establecida como para que la prueba presentada sea concluyente. En mi opinión, la prueba proporcionada por el sargento es la opinión de un experto y, por tanto, debe ser ponderada conforme a las reglas ordinarias que rigen las pruebas de opinión ${ }^{85}$.

Desafortunadamente para la Corona, el uso de la prueba caligráfica con fines de identificación estaba regulado por ley y permitía al experto estipular ${ }^{86}$. No había disposiciones similares para la identificación por huella dactilar. Cuando se presentaron dos huellas dactilares y se le pidió que diera una opinión, el experto simplemente se limitó a señalar «que las huellas dactilares fueron hechas por el mismo individuo. Eso es todo» ${ }^{87}$. Esto llevó a la Corte a la siguiente conclusión:

${ }^{82}$ R. v. De'Georgio and Servello [1934] 3 WWR 374.

83 Compárese con Bornyk I (más adelante), donde los materiales exógenos no son admitidos ni discutidos.

${ }^{84}$ DéGeorgio, [6]. Confróntese con lo señalado en el testimonio ofrecido por Cole y Harber en Mitchell.

85 DéGeorgio, [7].

86 Evidence Act, s48.

87 DéGeorgio, [8]. 
... la prueba del Sargento Peachey es solo una prueba de opinión y no se ha dado al Tribunal prueba suficiente satisfactoria de las razones de sus conclusiones. En otras palabras, él -para ponerlo en un lenguaje común- ha hecho las veces de juez. Eso no es para lo que él está aquí. Está aquí para ofrecer prueba que ayude al juez y al jurado a llegar a una conclusión.

No estoy convencido de que ningún jurado esté a salvo de llegar a un veredicto de culpabilidad solo con base en pruebas de opinión. Por ello, no creo que ningún jurado estuviese justificado para llegar a una conclusión de culpabilidad con base en pruebas de opinión en las que no se dieron razones satisfactorias que justifiquen dicha opinión ${ }^{88}$.

La forma en que se introdujo la prueba, presentada como un hecho en lugar de una opinión, y la ausencia de razones que la justificaran, jugaron a favor de su exclusión ${ }^{89}$.

En $R . v$. Wiswell, una huella dactilar encontrada en un vidrio roto asociado con un allanamiento de morada se atribuyó al recurrente ${ }^{90}$. Al parecer, el fiscal no había proporcionado una base suficiente para la prueba dactilar. La Corte Suprema de Nueva Escocia respondió:

La identificación por huellas dactilares es, en el mejor de los casos, una prueba de opinión basada en el conocimiento y la práctica de los expertos y, con el debido respeto, no creemos que esta base haya sido probada adecuadamente ${ }^{91}$.

Parece que el examinador de huellas dactilares había sido considerado competente por el mismo magistrado en otro caso el día anterior. Como explica la nota principal, «no es suficiente el hecho de que el experto haya sido considerado competente por el magistrado en otro caso el día anterior» ${ }^{92}$.

Las preocupaciones de la Corte acerca de las pruebas dactilares en Wiswell ampliadas a la identificación específica, «porque las pruebas que tenemos ante nosotros no muestran ni pretenden demostrar que las huellas dactilares en el cristal son las del prisionero» ${ }^{93}$. Para la Corte:

Incluso si se demostró razonablemente que las huellas dactilares son las del prisionero, bien se puede dudar más allá de toda duda razonable de que él ha sido el presunto ladrón ${ }^{94}$.

Los cinco jueces de apelación aceptaron que las pruebas de huellas dactilares latentes eran una opinión admisible, pero dudaban de si podían, por sí mismas, satisfacer el estándar de prueba más allá de toda duda razonable ${ }^{95}$.

La posición canadiense sobre el tema se puso en sintonía con el entonces enfoque ortodoxo internacional de R. v. Buckingham ${ }^{96}$. El Magistrado Robertson, basándose

88 DéGeorgio, [19]-[20].

89 No se tuvo en cuenta la fuerza del caso en general ni el papel de la prueba de huellas dactilares latentes en un caso circunstancial.

${ }_{90}$ R. v. Wiswell, [1935] 1 DLR 624, 63 CCC 94.

91 Wiswell, 95.

92 Wiswell, 94.

93 Wiswell, 94.

94 Wiswell, 94.

95 En este caso hubo también pruebas inconsistentes sobre el paradero del acusado en la noche de los hechos.

96 R. v. Buckingham [1946] 86 CCC 76. 
en las decisiones de Inglaterra, Escocia y los Estados Unidos (por ejemplo, Castleton, Bacon, Adair v McGarry y State v. Steffen $)^{97}$, consideró si la identificación mediante huellas dactilares podía sustentar una condena. Al explicar su fallo, además de su autoridad jurídica confió considerable cnfianza en el medio siglo su uso libre sin errores en Inglaterra:

Hoy la huella dactilar no es un sistema nuevo en ningún sentido. Fue sistematizado por primera vez gracias a los esfuerzos de Sir Edward Henry, quien vino de Bengala a Inglaterra en 1897 y luego se convirtió en inspector adjunto y luego en inspector jefe de la Policía Metropolitana de Londres. Véase Wills on Circumstancial Evidence, $7^{\mathrm{a}}$ ed., p. 205. El experto Vince dijo que nunca había cometido un error. No estaba alardeando cuando dijo eso, sino que estaba relatando el resultado de su experiencia. Advertí en la p. 210 en Wills que en los 32 años desde que se introdujo el sistema en Inglaterra ha habido más de 360,000 identificaciones y en ningún caso se ha cometido un error. Por lo tanto, no es nada nuevo, es algo antiguo y se ha vuelto cada año más científico, más correcto y menos susceptible de errores ${ }^{98}$.

Dada la confianza en este sistema de identificación, tal vez sea poco destacable que Robertson termina concluyendo que una sola huella dactilar coincidente puede ser suficiente para condenar. En esto se diferenció de Wiswell y DéGeorgio. Habiendo resuelto la cuestión, explicando que «la prueba de los expertos en huellas dactilares es una prueba de opinión y es admisible como tal», llamó al jurado para que escuchase la prueba ${ }^{99}$. El jurado absolvió al acusado.

Las decisiones canadienses «tempranas», como Wiswell, fueron lentamente revertidas a medida que los tribunales se adaptaban gradualmente a la posición complaciente de los otros tribunales de common law.

\subsection{Resumen}

Los casos reportados, como es obvio a veces, no representan necesariamente la primera vez que la identificación mediante huella dactilar latente se presentó ante un tribunal o que fue impugnada en estas jurisdicciones. En la mayoría, como en Inglaterra, hubo impugnaciones anteriores de la acusación y de la defensa. Ninguno de estos primeros juicios orales e impugnaciones, incluida la excepcionalmente elaborada impugnación en defensa de los hermanos Stratton o el procesamiento de Crispi, fue publicada en los reportes de casos. Esto es significativo porque las ideas y las críticas se perdieron para el derecho y la conciencia jurídica ${ }^{100}$. Las únicas decisiones a las que posteriormente hicieron referencia los tribunales de apelación, en apoyo de la admisión y especialmente de su uso, son las que se publicaron. Ninguna de las primeras decisiones reportadas expresa alguna preocupación por la prueba de huellas dactilares latentes (a excepción de la disidencia en Parker) y ninguna impone restric-

97 Adair v. McGarry 1933 S.L.T. 482 (1933) y State v. Steffen, 210 Iowa 196 (1930).

98 Buckingham, [10].

99 Buckingham, [22].

100 Por ejemplo, no hay ninguna referencia al libro de Fauld en Westlaw o Bailii.org en el Reino Unido. Incluso, casos populares publicados en la prensa fueron olvidados con el paso de los ańos. 
ciones sustanciales a la presentación de la prueba (antes de finales de siglo). Décadas más tarde se citan decisiones reportadas como Castleton, que se usan en apoyo de la admisibilidad y la capacidad de las pruebas de huellas dactilares latentes para probar la culpabilidad más allá de toda duda razonable.

Los casos reportados indican que el reconocimiento jurídico y la aceptación de pruebas de huellas dactilares latentes no se basaron en investigaciones científicas sobre su validez y su fiabilidad. Más bien, los jueces y los tribunales confiaron en la experiencia de los practicantes, sus creencias y dichos (en gran parte no probados), sus escritos publicados, su relevancia en el juicio mismo, junto con su uso y recepción (en otras jurisdicciones). En la mayoría de estas jurisdicciones no hay ninguna decisión reportada que establezca su reconocimiento formal y ofrezca una explicación para su admisión basada en investigación científica demostrativa ${ }^{101}$. A pesar de varias referencias confiables de autoridades que le daban apoyo a que las pruebas dactilares eran «fiables» e incluso de "experimentos», los primeros estándares de admisibilidad no dirigieron su atención a las capacidades reales ni a la tasa de error ${ }^{102}$. Más bien, tendían a centrarse en analogías con otros tipos de pruebas (por ejemplo, testigos presenciales, prueba caligráfica y la fotografía) y en sustitutos como la capacitación, los estudios, la experiencia, el uso prolongado, la existencia de agencias, reconocimiento por parte de otros tribunales y desempeńo libre de errores.

Basados en su entrenamiento y experiencia y en $e l$ hecho de que las huellas dactilares son únicas y permanentes, los examinadores de huellas dactilares latentes insistieron en que podían identificar positivamente a las personas con poco o ningún riesgo de error ${ }^{103}$. Los tribunales aceptaron estas afirmaciones, admitieron las pruebas dactilares como herramientas de identificación positiva, en muchas circunstancias capaces de satisfacer el estándar de prueba más allá de toda duda razonable. Cualquier problema o limitación de la prueba dactilar iba a juicio oral, en la pequeña proporción de casos en que la prueba de huellas dactilares fue impugnada. Antes de la aparición de los perfiles de ADN, para los abogados y los jueces, la prueba de huellas dactilares latentes parece haber sido una de las pruebas más convincentes conocidas por el derecho ${ }^{104}$. El puñado de abogados defensores que se cuestionaron sobre el desempeño de los examinadores de huellas dactilares, el índice de error, las investigaciones científicas que la sustentaran u otras limitaciones, se encontraron con respuestas confiadas, basadas en las creencias de los examinadores de huellas dactilares, en lugar de pruebas derivadas de investigaciones científicas independientes ${ }^{105}$.

101 Sin embargo, muchas de las decisiones analizadas en esta muestra han sido tratadas posteriormente como si hiciesen precisamente aquello.

102 El significado jurídico de fiabilidad ha ido cambiando en el tiempo.

$103 \mathrm{Su}$ principal asociación profesional, la International Association for Identification (IAI) [en español: Asociación Internacional para la Identificación], en realidad les exigía que hicieran solo identificaciones positivas y descartaran la posibilidad de error (al menos en el método).

104 Lynch, et al, 2008. Tal vez las admisiones fueron más poderosas en los años anteriores a que nos familiarizásemos con la incidencia de las confesiones falsas. Véase Gudjonsson, 2002.

105 SAKs y Koehler, 2005. 


\section{CONSOLIDACIÓN: UN SIGLO DE IMPUGNACIONES NO EPISTÉMICAS (1909-1998 Y DESPUÉS)}

En este numeral se considerarán las impugnaciones a la prueba dactilar latente desde sus orígenes en el common law hasta el primer cuestionamiento epistemológico reportado a finales de siglo en Estados Unidos v. Mitchell en 1998. Después de Castleton en 1909, este período abarca todo el siglo xx; e incluso más tiempo en la mayoría de las jurisdicciones analizadas. Las impugnaciones y las decisiones consideradas a continuación consolidaron no solo la admisibilidad de la prueba dactilar latente, sino que también, en muchos casos explícitamente, su fiabilidad (jurídica) ${ }^{106}$. Como veremos, a través de una muestra de las muchas impugnaciones y apelaciones, los fundamentos epistemológicos de la prueba dactilar latente casi nunca fueron cuestionados. En consecuencia, casi todos los intentos por excluir o limitar el uso de las pruebas dactilares eran con fundamentos jurídicos.

La mayoría de las impugnaciones a las huellas dactilares latentes se asemejan a los tipos de problemas preestablecidos por Castleton, Parker, Blacker y las distintas decisiones canadienses. La mayoría de las impugnaciones se centran en cuestiones de procedimiento: como supuestas irregularidades en la recopilación y el almacenamiento de las huellas dactilares; si es que la identificación mediante huellas dactilares es capaz de satisfacer el estándar probatorio penal; si es que tener registradas previamente las huellas dactilares de un acusado resulta injusto, ya que implícitamente prejuzga su mal carácter; si es que la prueba dactilar contraviene los derechos constitucionales (o los derechos consagrados en la emergente Carta de Naciones Unidas); la calidad de los informes de huellas dactilares; el uso de fotografías (por ejemplo, mostrando huellas marcadas); si los examinadores de huellas dactilares latentes proporcionaron testimonios que traspasan su "competencia" definida jurídicamente; y el rol de los juzgadores de los hechos en relación con la opinión experta y la comparación de huellas ${ }^{107}$. Algunas de las impugnaciones fueron exitosas, pero la mayoría no. En la gran mayoría de estos casos, y los que analizaremos a partir de ahora, son simplemente la punta del iceberg, las pruebas de huellas dactilares latentes fueron admitidas y consideradas como prueba cierta de la identidad de los sujetos ${ }^{108}$. De manera invariable, las decisiones consideran que la capacidad y las opiniones de los examinadores están fuera de toda duda.

No es mi intención trivializar las impugnaciones jurídicas (o no epistémicas). Más bien, sirve para ilustrar cómo los abogados y los tribunales dieron por sentada la fia-

106 Esta posición se mantendría hasta que el perfil de ADN la reemplazara en los ańos noventa. La institucionalización y el reconocimiento jurídico están íntimamente ligados.

107 Los casos reportados representan solo un pequeño porcentaje de las investigaciones, acusaciones y condenas que se sustentan en pruebas dactilares.

${ }_{108}$ Muchos de estos cuestionamientos no epistémicos se superponen a una variedad de cambios y desarrollos socio-jurídicos, o se extienden más allá, como las críticas científicas, los proyectos inocencia y las condenas erróneas, así como cambios en las reglas probatorias y del proceso que regulan la prueba pericial, discutido en la Sección 5. 
bilidad de la prueba dactilar latente, en su forma más fuerte como prueba positiva de identidad. Casi ninguna impugnación a la prueba de huellas dactilares latentes antes de 1998, y casi ninguna de las impugnaciones fuera de los EE.UU., se refirió sustancialmente respecto a la validez, la fiabilidad científica, la capacidad, la incertidumbre, la forma de expresar o la realidad del error. Algunas de estas impugnaciones jurídicas fueron efectivas y, en su momento, eran probablemente la forma más efectiva de promover el interés de sus clientes. Sin embargo, nos muestra cómo los abogados y los jueces aceptaron crédulamente las afirmaciones de los examinadores de huellas dactilares y los precedentes de los tribunales sobre que las pruebas de huellas dactilares latentes supuestamente eran pruebas infalibles de identidad basadas en la unicidad de las huellas dactilares humanas. Las decisiones reportadas y sus considerandos nos ayudan a comprender cómo las generaciones anteriores de jueces, preocupados con reglas y problemáticas socio-jurídicas diferentes a las de hoy, restringieron a los que les siguieron.

La escasez (en realidad la ausencia) de desafíos epistemológicos anteriores a Daubert v. Merrell Dow Pharmaceuticals, Inc. (1993, y US v. Mitchell en 1998) es aún más curiosa porque hubo cambios drásticos en la forma en que se recolectaban, procesaban, almacenaban, buscaban y analizaban las huellas dactilares latentes a lo largo del siglo $\mathrm{Xx}^{109}$. La recolección comenzó haciéndose levantando y analizando los objetos, usando cintas adhesivas y fotografías. Inicialmente, el examen se hacía a simple vista y ayudado con el uso de lupas. Las impresiones de referencia se obtenían de los sospechosos (a menudo de manera informal, como en Blacker y Cerciello) y los crecientes registros de huellas se indexaban y buscaban manualmente ${ }^{110}$. Para finales del siglo, existía una serie de nuevas técnicas en uso, algunas de ellas utilizando productos químicos e iluminación para identificar y mejorar las impresiones latentes en una amplia gama de sustratos. Mientras que las impresiones de las huellas continuaban levantándose mecánicamente, ahora la mayoría se capturan con cámaras digitales y se almacenan electrónicamente. Las impresiones son rutinariamente manipuladas y mejoradas utilizando programas informáticos especializados y algoritmos patentados permiten la búsqueda rápida en bases de datos electrónicas masivas.

Hacia finales del siglo xx, el ACE-V surgió como el principal «método» utilizado por los examinadores de huellas dactilares latentes ${ }^{11}$. La resolución del «método» no resolvió las inconsistencias en torno a los estándares y la cantidad de puntos requeridos por los departamentos de policía y las agencias para estar dispuestos a declarar la existencia de una coincidencia ${ }^{112}$. Muchas agencias abandonaron for-

109 Daubert v Merrell Dow Pharmaceuticals, Inc 113 S Ct 2786 (1993).

110 Véase Cole, 2001.

111 La primera referencia reportada sobre el 'ACE-V' en Westlaw, aparece en casos federales en U.S. v. Havvard, 117 F.Supp.2d 848 (S.D. Ind. 2000) y en casos estatales en Burnett v. State, 815 N.E.2d 201 (2004).

112 Las distintas agencias, e incluso los individuos dentro de cada agencia, no utilizaban el método de la misma manera. Generalmente había bastante discrecionalidad en la forma en que se aplicaba y pocos estándares empíricos. 
malmente el sistema de puntos antes de finales de siglo; y mucho antes de que los tribunales consideraran el tema. En este y los siguientes numerales observaremos cómo tales reorientaciones de inspiración científica hicieron poca diferencia en la práctica y la comprensión jurídica sobre el tema. Curiosamente, las reformas tecnológicas y sus implicaciones probatorias reciben muy poca atención en las decisiones reportadas.

Además, la organización de las agencias de huellas dactilares y la formación de los examinadores cambiaron notablemente a lo largo del siglo xx. Los pequeños grupos que existieron en las primeras décadas del siglo xx se expandieron y consolidaron en los departamentos de policía y las agencias de investigación. Simultáneamente, la formación se comenzó a formalizar a partir de los años veinte y treinta. En algunas jurisdicciones, especialmente en Inglaterra, Canadá y Australia, la capacitación tardaba años en los que los examinadores tenían que ser socializados lentamente en las agencias de huellas dactilares y su dogma ${ }^{113}$. Históricamente, la mayoría de los examinadores de huellas dactilares eran policías. Pocos tenían titulaciones superiores. En años más recientes, muchos departamentos de policía han comenzado a contratar a personas con títulos en ciencias forenses o en ciencias y a confiar más en los examinadores de huellas dactilares civiles.

Paralelamente a la expansión de las agencias de huellas dactilares y la rutinización del uso de las pruebas dactilares para la identificación de personas, se comenzó a promulgar legislación que permitía a los investigadores recopilar y almacenar las huellas dactilares de sospechosos y delincuentes condenados. Esta legislación tendió a ser más permisiva, expandiendo gradualmente los grupos cuyas huellas dactilares podrían ser legalmente recolectadas y almacenadas. Este numeral documenta cómo esta legislación más permisiva, que a través de sus ambigüedades y omisiones legislativas y supuestas infracciones de procedimientos, se convirtió en la principal forma de impugnar la admisión de pruebas de huellas dactilares latentes ante tribunales.

No es sorprendente que los abogados se centraran en cuestiones jurídicas en sus intentos de cuestionar la admisibilidad y el uso de pruebas de huellas dactilares. Sin embargo, sí es notable cuán pocas de las muchas impugnaciones cuestionaron el ACE-V, las nuevas tecnologías, las significativas pretensiones epistémicas de identificación positiva (llegando a excluir a todas las demás personas) y las afirmaciones de una tasa de error cero. Este numeral sugeriría que las impugnaciones viables no solo dependen de las reglas y los procedimientos, sino también (y fundamentalmente) de la conciencia judicial. Es decir, el éxito de las impugnaciones no solo está determinado por la forma en que los jueces interpretan el derecho, sino que, inevitablemente, también por cómo entienden la prueba y la legitimidad de las alegaciones de las defensas ${ }^{114}$.

113 SAKS y FaIGMAN, 2008: 149.

114 Véase e.g. Lo PUCKI, 1996: 1498. 


\subsection{Admisibilidad y otras impugnaciones en los Estados Unidos}

En los Estados Unidos ${ }^{115}$, antes de Daubert (y EE. UU. v. Mitchell), las impugnaciones a la prueba de huellas dactilares latentes se centraban principalmente en cuestiones procedimentales (i.e. debido proceso), constitucionales y de otra índole, que no estaban directamente relacionadas con la validez y la fiabilidad científica. Por ejemplo, muchos casos se centraban en las circunstancias en que las huellas dactilares del acusado se recogieron ${ }^{116}$; si la toma de huellas dactilares o la presentación de las mismas violaron la cuarta, la quinta, la sexta o la catorceava enmiendas de la Constitución $^{117}$; la posibilidad de recoger o utilizar las huellas dactilares de menores de edad $^{118}$; si el examinador de huellas dactilares debería estar presente cuando se recolectaran las huellas dactilares de referencia ${ }^{119}$; si un examinador de huellas dactilares tiene que declarar personalmente cuando emite un certificado (en procedimientos militares) ${ }^{120}$; si la entrega de la huella dactilar debe ser voluntaria (en analogía a una confesión) ${ }^{121}$; problemas con la cadena de custodia ${ }^{122}$; la fiabilidad de los registros de huellas dactilares ${ }^{123}$; si el retraso en la presentación debería impedir la admisión de

115 Para casos estadounidenses, la búsqueda en Westlaw fue «(fingerprint OR finger-print OR “finger print")/s admiss! » utilizando tanto la base de datos estatal como federal. Debido al gran número de casos encontrados con estos criterios, esta muestra se basa solo en los 100 primeros casos mostrados en cada base de datos (ordenados según su relevancia) con preferencia en casos resueltos con anterioridad a la apelación en U.S. $v$. Mitchell. Adicionalmente, se buscó en Westlaw el término "fingerprint" en el mismo párrafo que los términos: "AFIS» (y sus derivados), «database» y otras técnicas específicas (por ejemplo, «superglue»). En otras jurisdicciones en las que el número de resultados fue menor de 100 (por ejemplo 84 en Canadá), todos los casos fueron revisados. Este método parece abarcar de manera suficiente las decisiones informadas en jurisdicciones no-estadounidenses y los resultados de esta búsqueda son bastante consistentes a lo largo de todas las jurisdicciones.

116 Véase e.g. Singleton v Estelle, 492 F.2d 671 (5th Cir. 1974); U.S. v. Lyles, 471 F.2d 1167 (5th Cir. 1974); Schleicher v. Wyrick, 529 F.2d 906 (8th Cir. 1976); Louie v. U.S., 426 F.2d 1398 (9th Cir. 1970). Estatal: Paramore v. State, So.2d 344 (1971).

117 Federal: Michaels v. U.S., 917 F.2d 566 (9th Cir. 1990); U.S. v. Gibson, 444 F.2d 275 (5th Cir. 1971); Pearson v. U.S., 389 F.2d 684 (5th Cir. 1968); U.S. v. Iacullo, 226 F.2d 788 (7th Cir. 1955); Paulson v. State of Fla., 360 F.Supp. 156 (S.D. Florida, 1973). Estatal: Whippler v. State, 218 Ga. 198 (1962); People v. Jones, 112 Cal.App. 68 (1931); People v. One 1941 Mercury Sedan, 74 Cal.App.2d 199 (1946); People v. Gates, 24 N.Y.2d 666 (1969); Com. v. Richardson, 476 Pa. 571 (1978); State v. Padilla, 92 N.M. 19 (1978); Grimes v. U.S., 405 F.2d 477 (5th Cir. 1968); U.S. v. Taylor, 4 USCMA 232 (1954); U.S. v. Caudillo-Infante, 233 Fed.Appx. 619 (9th Cir. 2007); Gregory v. U.S., 391 F.2d 281 (9th Cir. 1968); U.S. v. Ortiz-Gonzalbo, 946 F.Supp. 287 (S.D. N.Y. 1996); Carvey v. LeFevre, 611 F.2d 19 (2nd Cir. 1979); U.S. v. Mouzin, 785 F.2d 682 (9th Cir. 1986); U.S. v. Thomann, 609 F.2d 560 (1st Cir. 1979). State: Paulson v. State, 257 So.2d 303 (1972) (si es que una huella dactilar en particular era «fruto del árbol envenenado»).

118 State v. Carder, 9 Ohio St.2d 1 (1966).

119 Clay v. State, 440 N.E.2d 466 (1982).

120 U.S. v. Taylor, 24 USCMA 232 (1954).

121 Com. v. Rocci, 18 Berks 274 (1926).

122 Federal: U.S. v Jeffords, 491 F.2d 90 (5th Cir. 1974); U.S. v. Morgan, 559 F.2d 397 (5th Cir. 1977); U.S. v. Thomann, 609 F.2d 560 (1st Cir. 1979); Scott v. Jones, 915 F.2d 1188 (8th Cir. 1990). Estatal: Howell v. State, 627 So.2d 1134 (1993).

123 U.S. v. Grey, 531 F.2d 933 (8th Cir. 1976). 
pruebas de huellas dactilares ${ }^{124}$; si es injusta la implicación de que el acusado tenía antecedentes penales (o mal carácter), porque sus huellas dactilares estaban archivadas en un registro ${ }^{125}$; si los registros de huellas dactilares son testimonios de oídas inadmisibles ${ }^{126}$; si era admisible una identificación realizada usando huellas dactilares de un registro en lugar de huellas dactilares posteriores al arresto ${ }^{127}$; si en el caso de que se cuestionara la calidad de las huellas dactilares latentes, podrían utilizarse de todas formas para identificar a un delincuente ${ }^{128}$; si un examinador de huellas dactilares podría declarar acerca del hecho principal en juicio ${ }^{129}$; si se requirieron fotografías ampliadas de las impresiones para explicar la prueba ${ }^{130}$; si el uso de flechas en las imágenes de huellas dactilares que apuntan a supuestas similitudes constituye un error perjudicial $^{131}$; si las huellas dactilares encontradas en un objeto portátil son admisibles para determinar la presencia del acusado en un lugar específico ${ }^{132}$; si el objeto desde el que se recuperó la huella dactilar tiene que ser admisible y admitido como prueba para que la prueba de la huella dactilar sea también admitida ${ }^{133}$; si era necesario probar que una huella dactilar fue puesta en un momento determinado para hacerla admisible en un caso conformado con pruebas circunstanciales ${ }^{134}$; la importancia de la posibilidad de que se tratase de un "contacto inocente» ${ }^{135}$; si las huellas dactilares latentes de una escena del crimen que no pudieron identificarse afectan la admisibilidad de las huellas dactilares identificadas ${ }^{136}$; si son admisibles las explicaciones sobre las razones por las cuales no se pudieron recuperar impresiones de huellas dactilares ${ }^{137}$; si un examinador de huellas dactilares del FBI podía declarar que las huellas dactilares solo se recuperaron en una pequeña proporción de robos a bancos ${ }^{138}$; si los informes de huellas dactilares negativos (es decir, sin hallazgos o identificaciones) pueden divulgarse según

124 U.S. v. Edmonson, 962 F.2d 1535 (10th Cir. 1992).

125 U.S. v. Mancini, 396 F.Supp. 75 (E.D. Pa, 1973); U.S. v. Malizia, 503 F.2d 578 (2nd Cir. 1974). See also Morgano v. Pilliod, 299 F.2d 217 (7th Cir. 1962); Newsom v. U.S., 402 F.2d 835 (5th Cir. 1968); Bates v. Chapleau, 37 F.3d 1498 (6th Cir. 1994); Riley v. Sigler, 320 F.Supp. 96 (D. Nebraska, 1970); U.S. v. Gocke, 507 F.2d 820 (8th Cir. 1974); U.S. v. Farley, 292 F.2d 789 (2nd Cir. 1961).

126 Federal: U.S. v. Dancy, 861 F.2d 77 (5th Cir. 1988); U.S. v. Thornton, 209 Fed.Appx. 297 (4th Cir. 2006). Estatal: State v. Lee, 577 So.2d 1193 (1991); Young v. State, 508 N.E.2d 24 (1987).

127 U.S. v. Jackson, 451 F.2d 259 (5th Cir. 1971).

128 Alcorn v. State, 415 S.W.2d 666 (1967).

129 U.S. v. Hagelberger, 153 USCMA 259 (Court of Military Appeals, 1953); U.S. v. Sherwood, 98 F.3d 402 (9th Cir. 1996) (y admisible bajo el «criterio general» Daubert).

130 U.S. v. Alexander, 868 F.2d 492 (1st Cir. 1989). Estatal: State v. Short, 322 N.C. 783 (1988) (en especial cuando las huellas originales están disponibles).

131 U.S. v. Gray, 464 F.2d 632 (8th Cir. 1972).

132 State v. Nabozny, 54 Ohio St.2d 195 (1978).

133 State v. Broom, 114 Wis.2d 591 (1983).

134 State v. Irick, 291 N.C. 480 (1977); State v. Futrell, 112 N.C.App. 651 (1993); State v. Bost, 33 N.C.App. 673 (1977). Véase también U.S. v. Griffin, 483 F.2d 957 (5th Cir. 1973); U.S. v. Henderson, 588 F.2d 157 (5th Cir. 1979).

135 U.S. v. Scott, 784 F.2d 787 (7th Cir. 1986).

136 State v. Hall, 262 So.2d 498 (1972); State v. Wimberly, 246 Kan. 200 (1990).

137 U.S. v. Phillips, 575 F.2d 97 (6th Cir. 1978).

138 U.S. v. Christophe, 833 F.2d 1296 (9th Cir. 1987). 
la decisión en Brady v. Maryland ${ }^{139}$ u otra regla de descubrimiento de pruebas ${ }^{140}$; si la prueba de huellas dactilares latentes es necesaria para fundar la acusación ${ }^{141}$; si las similitudes entre las huellas dactilares de referencia y las huellas latentes (que no fueron suficientes para fines de identificación) pueden sustentar una condena junto con otras pruebas ${ }^{142}$; si fue un error permitir al jurado comparar las huellas dactilares (incluso cuando los antecedentes penales del acusado estaban al reverso de la tarjeta de referencia) ${ }^{143}$; si la incapacidad para satisfacer el número de puntos requeridos por el FBI (12 puntos en la década de 1970) afectaba el peso o la admisibilidad de la prueba ${ }^{144}$; si un examinador podía declarar acerca de la antigüedad de una impresión dactilar ${ }^{145}$; las consecuencias de no prestar asistencia experta a la defensa ${ }^{146}$; e incluso la admisibilidad del cálculo numérico especulativo de probabilidades presentados por un examinador ${ }^{147}$. Estas impugnaciones se resolvieron a favor de los Estados.

Los problemas sobre la suficiencia de la capacitación de un examinador se consideraron cuestiones que impactaban en el peso de la prueba ${ }^{148}$. Del mismo modo, la inexperiencia de un examinador era un problema de peso ${ }^{149}$. Incluso la confesión de un examinador de que él no se consideraba a sí mismo un experto, solo afectaría el peso de su opinión, no a su admisión ${ }^{150}$. Una apelación presentada por asistencia letrada ineficaz, basada en que el abogado no impugnó la prueba de huellas dactilares latentes, se rechazó de manera perentoria: «la prueba de huellas dactilares era relevante para determinar la identidad y fue admitida adecuadamente, por lo que no parece haber ninguna base para objetar la admisión de esta prueba» ${ }^{151}$.

En Texas, un examinador podía declarar que ninguna otra persona podría haber dejado tal huella y, relativamente temprano, la carga de probar que dos huellas dactilares podrían ser iguales se convirtió en responsabilidad del acusado ${ }^{152}$. En Nueva Jer-

139 Squires v. Dugger, 794 F.Supp. 1568 (M.D. Florida, 1992); Ware v. U.S., 971 F.Supp. 1442 (M.D. Florida, 1992).

140 U.S. v. Papajohn, 848 F.Supp. 334 (E.D. NY, 1994). Véase Brady v. Maryland, 373 US 83 (1963).

141 U.S. v. Roberts, 481 F.2d 892 (5th Cir. 1973); U.S. v. Abigando, 439 F.2d 827 (5th Cir. 1971).

142 U.S. v. Harris, 530 F.2d 576 (4th Cir. 1976).

143 U.S. v. Dressler, 112 F.2d 972 (7th Cir. 1940). Estatal: State v. Bogan, 183 Ariz. 506 (1995).

144 People v. Gomez, 189 Colo. 91 (1975).

145 U.S. .v Trice, 476 F.2d 89 (9th Cir. 1973). Asimismo, sobre la incapacidad de determinar la antigüedad de la muestra U.S. v. Roberts, 481 F.2d 892 (5th Cir. 1973).

146 U.S. v. Walborn, 730 F.2d 192 (5th Cir. 1984). En State v. Lewis, 7 N.C.App. 178 (1970), la solicitud de la defensa para que examinadores de huellas dactilares y estadísticos revisaran la prueba del Estado fue considerada desistida, ya que el recurrente no fue capaz de seńalar un costo aproximado.

147 Hicks v. Scurr, 671 F.2d 255 (8th Cir. 1982).

148 State v. Pennye, 104 Ariz. 146 (1969); State v Watson, 99 Idaho 694 (1978).

149 State .v Russell, 434 So.2d 460 (1983).

150 Sharpe v. State, 490 S.W.2d 834 (1973).

151 Thomas v. State, 547 A.2d 634 (1988). Véase también Jones v. Clarke, 783 F.3d 987 (4th Cir. 2015); Katschor v. Grayson, 9 F.3d 108 (6th Cir. 1993). Sin embargo, compárese con Atkins v. Attorney General of State of Alabama, 932 F.2d 1430 (11th Cir. 1991).

152 Grice v. State, 151 S.W.2d 211 (1941). 
sey, las pruebas dactilares se caracterizaron como «reconocidas universalmente como prácticamente determinantes sobre la identidad de un sujeto» ${ }^{153}$. El caso Jennings «reconoció la admisibilidad de la prueba dactilar en el caso después de concluir que existía una "base cientifica para el sistema de identificación de huellas dactilares» ${ }^{154}$. Este tipo de compromisos se repitieron a menudo, como en el siguiente extracto:

La admisibilidad de la prueba dactilar se basa en la suposición, aceptada universalmente, de que el patrón de huellas dactilares de cada individuo solo puede producirse por el contacto del dedo de ese individuo con otro objeto ${ }^{155}$.

Aunque se reconoce que la prueba de huellas dactilares y de las palmas de la mano son pruebas circunstanciales y de opinión en su naturaleza, es su gran fiabilidad la razón básica del reconocimiento universal de su admisibilidad para establecer la identidad de un sujeto. Es el tipo de prueba más sólida ${ }^{156}$.

Cuando un cuestionamiento de admisibilidad llegó finalmente a la Corte de Apelaciones de Maryland en Murphy v. State, el tribunal se sintió obligado a tener como «hecho notorio el hecho de que el uso de huellas dactilares es un medio infalible de identificación» ${ }^{157}$.

Las cuestiones planteadas en el pequeño porcentaje de impugnaciones jurídicas y apelaciones exitosas fueron, una vez más, más bien jurídicas que epistémicas. Incluían: si una huella dactilar encontrada en un arma utilizada para matar a una persona podría, sin más, satisfacer el estándar de prueba penal ${ }^{158}$; de manera similar, si una huella dactilar encontrada en una caja de cerillas utilizada para mantener una puerta abierta durante un robo, podría respaldar por si sola la condena ${ }^{159}$; el tribunal impidió que el abogado defensor interrogara a un examinador de huellas dactilares sobre la importancia de la ausencia de huellas dactilares en las drogas que se encontraron en su posesión ${ }^{160}$; el error en declarar como prueba inadmisible unas huellas dactilares no identificadas recuperadas de una botella de vodka que se encontraba adyacente al difunto ${ }^{161}$; y la recolección ilegal de huellas dactilares ${ }^{162}$. En las primeras décadas, algunos tribunales, como la Corte Suprema de Iowa, estaban divididos

153 Cortese v. Cortese, 10 N.J.Super. 152 (1950). Véase también Com. v. Woodward, 17 Pa. D. \& C. 400 (1932).

154 People v. Ferguson, 172 Ill.App.3d 1 (1988). Véase también State v. Clark, 156 Wash. 543 (1930); Stacy v. State, 49 Okla.Crim. 154 (1930).

155 Baker v. State, 470 N.E.2d 346 (1984); Medias v. City of Indianapolis, 216 Ind. 155, 167 (1939). Véase también Bruce v. State, 268 Ind. 180 (1978).

156 Nichols v. State, 462 So.2d 992 (1984) (referencias eliminadas).

157 Murphy v. State, 184 Md. 70, 85-86 (1944). Véase también Reed v. State, 283 Md. 374 (1978).

158 Sin embargo, la prueba dactilar puede, bajo determinadas circunstancias, establecer la responsabilidad: Blanco v. State, 485 So.2d 1217 (1986).

159 U.S. v. Corso, 439 F.2d 956 (4th Cir. 1971). Compárese con U.S. v. Harris, 530 F.2d 576 (4th Cir.1976) donde las huellas dactilares encontradas en objetos móviles pueden, no obstante, ser consideras como prueba.

160 U.S. v. Thompson, 37 F.3d 450 (9th Cir. 1994).

161 Corley v. State, 335 So.2d 849 (1976).

162 Cook v. Johnson, 459 F.2d 473 (6th Cir. 1972). 
sobre si un examinador de huellas dactilares podía opinar sobre la identidad de un sujeto, cuando esta era precisamente el hecho principal de la causa ${ }^{163}$.

Sobre la aparición de nuevas tecnologías (por ejemplo, el AFIS), las referencias son casi todas simples menciones o breves descripciones ${ }^{164}$. Parece haber habido un interés extremadamente limitado sobre las bases de datos, los algoritmos, las mejoras y los nuevos procedimientos de recopilación y creación de imágenes. En People v. Edwards, la incapacidad de explicar por qué las huellas del acusado no fueron localizadas inicialmente a través de una búsqueda con AFIS fue apenas mencionada ${ }^{165}$. Hay casos en los que se menciona el AFIS en relación con las implicaciones de revelar que las huellas dactilares del acusado están en una base de datos que contiene principalmente antecedentes de delincuentes ${ }^{166}$. Hay casos en los que se discute si las impresiones dactilares de un menor pueden subirse en el sistema AFIS ${ }^{167}$. Entre las pocas decisiones más dedicadas al asunto, se plantean cuestiones como el hecho de que el Estado no haya procesado a través del AFIS unas huellas dactilares latentes no identificadas encontradas en una escena del crimen ${ }^{168}$. En el caso State $v$. Feldman, el abogado de la defensa solicitó información sobre el funcionamiento del sistema AFIS y el conjunto de candidatos que generaba esta búsqueda ${ }^{169}$. Esto fue resistido por el Estado; con el fiscal calificando dicha información como «irrelevante» ${ }^{170}$. El hecho de que el AFIS no conservara el grupo de candidatos no se interpretó como destrucción de prueba, sino un problema que la defensa debe plantear en juicio para ser considerado por el jurado ${ }^{171}$. Entre los casos que se refieren al AFIS (o bases de datos de huellas dactilares) encontramos procedimientos civiles, en los que se determinó que exigir como requisito para obtener asistencia pública que las personas entreguen y suban sus impresiones dactilares personales al AFIS, no es incompatible con las garantías constitucionales ${ }^{172}$, y algunos litigios contractuales y sobre derechos de propiedad asociados con el suministro de sistemas AFIS a las fuerzas policiales ${ }^{173}$.

Hay un puñado de impugnaciones a la admisibilidad de las nuevas tecnologías. Concebidas de forma restringida y generalmente de manera superficial, cuestionan

163 State v. Steffen, 210 Iowa 196 (1930).

164 Federal: U.S. v. Pimentel, 1995 WL 745009. Estatal: State v. Waller, 1997 WL 20914; People v. Manley, 222 Ill.App.3d 896 (1991); State v. Lovings, 1997 WL 798328 (número de búsquedas AFIS por examinador); People v. Smith, 256 Ill.App.3d 610 (1994); People v Saunders, 235 Ill.App.3d 661 (1992); State v. Ellis, 1996 WL 496930; State v. Gilmer, 604 So.2d 117 (1992); State v Johnson, 943 S.W.2d 285 (1997); Farley v. State, 225 Ga.App. 687484 S.E.2d 711 (1997); People v Hickey, 178 Ill.2d 256 (1997).

165 People v. Edwards, 241 Ill.App.3d 839 (1993).

166 State v. Elliott, 1996 WL 733140; Black v State, 680 So.2d 942 (1995); State v. Staten, 1996 WL 339953.

167 In re Abraham F., 190 Ariz. 359 (1997).

168 Newsome v. James, 968 F.Supp. 1318 (N.D. Ill. 1997).

169 State v. Feldman, 254 N.J.Super. 754 (1992).

170 State v. Feldman, 756.

171 State v. Feldman, 759.

172 Buchanan v. Wing, 664 N.Y.S.2d 865 (1997).

173 State ex rel. Fisher v. PRC Pub. Sector, Inc., 99 Ohio App.3d 387 (1994). 
los tratamientos digitales realizados a las imágenes para mejorar la búsqueda y comparación ${ }^{174}$ y el uso de la «técnica del súper-pegamento» (o cianoacrilato) para procesar y visualizar las huellas dactilares latentes ${ }^{175}$. En uno de los dos casos reportados respecto al súper-pegamento, un tribunal estatal rechazó la impugnación usando Frye (es decir, la aceptación general) por los siguientes motivos:

En los casos en que, como este, un procedimiento aísla la prueba física cuya existencia, apariencia, naturaleza y significado son obvios para los sentidos de un lego, la fiabilidad del proceso para producir dicho resultado es igualmente evidente y no es necesario debatirla bajo los estándares de Kelly [es decir Frye] ${ }^{176}$.

El Tribunal de Apelaciones de Virginia (en 2006) parece haber sido el único tribunal en encontrar que esta «nueva» técnica planteaba ciertas dudas sobre su admisibilidad ${ }^{177}$.

\subsection{Admisibilidad y otras impugnaciones en el Reino Unido}

En el Reino Unido (incluida Escocia en este apartado) ${ }^{178}$, la mayoría de las impugnaciones se centran nuevamente en cuestiones procedimentales, en particular si las circunstancias en las que se obtuvieron las huellas dactilares permitían que fueran usadas para demostrar la identidad de un sujeto en juicio oral, ${ }^{179}$ junto con la necesidad de advertir al imputado antes de tomarle las muestras ${ }^{180}$. Otras impugnaciones y apelaciones se centran en: qué es necesario realizar para probar que un registro de huellas dactilares pertenece al acusado ${ }^{181}$; si la legislación que autoriza la recolección de huellas dactilares se extiende también a las huellas de las palmas ${ }^{182}$; si los registros de huellas dactilares son una excepción a las reglas sobre testimonios de oídas ${ }^{183}$; y las consecuencias de la no divulgación y destrucción de pruebas de huellas dactilares ${ }^{184}$.

174 State v. Hayden, 90 Wash.App. 100 (1998).

175 People v. Eyler, 133 Ill.2d 173 (1989).

176 People v. Webb, 6 Cal.4th 494 (1993).

177 Hasson v. Com., 2006 WL 1387974.

178 Para los casos de Reino Unido, la búsqueda en Westlaw incluye todos los tribunales, incluso los tribunales escoceses, en orden para disminuir las omisiones.

179 Public Prosecution Service v. McKee, [2013] 2 Cr. App. R. 17 (falló en el uso de un dispositivo aprobado); Rv. Reay (Thomas Michael), 2003 WL 21236465; Chester-Nash v. Crown Prosecution Service, 2000 WL 571246; R v. Murray (Aaron Elvis), [2018] EWCA Crim 1252; Prendi v Albania, [2015] EWHC 1809 (Admin); Djalo v. United Kingdom (Admissibility) (17770/10), (2018) 66 E.H.R.R. SE14 Scotland: HM Advocate v Shepherd (Kenneth Matthew), 1997 J.C. 131; HM Advocate v. Shepherd (Kenneth Matthew), 1997 S.L.T. 891; Namyslakv HM Advocate, 1995 S.L.T. 528; Cairns (Peter John) v. HM Advocate, 1999 S.L.T. 1072; Davidson (William James) v. HM Advocate, 1951 J.C. 33; Geddes (Ian) v HM Advocate, 2015 S.C.L. 334 (no tuvo una defensa experta).

180 Callis v. Gunn, (1964) 48 Cr. App. R. 36 (no hubo ninguna advertencia).

181 Chappell v. DPP, (1989) 89 Cr. App. R. 82.

$182 R v$. Tottenham Justices Ex p. L (Mark), (1986) 82 Cr. App. R. 277

${ }^{183} R v$. Rodgers (Robert), [2013] NICA 71.

${ }^{184} R v$ v. Lesley (Leroy Owen) [1996] 1 Cr. App. R. 39 
En las últimas décadas, muchos de los cuestionamientos han sido influenciados por el Convenio Europeo de Derechos Humanos (CEDH).

Las referencias a los sistemas y bases de datos AFIS aparecen principalmente en relación con la conservación y el uso de huellas dactilares, conforme al art. 8 de la $\mathrm{CEDH}^{185} \mathrm{y}$ (otras) apelaciones de refugiados e inmigrantes ${ }^{186}$. En una reclamación sobre la identificación de un ciudadano extranjero basada en huellas dactilares latentes, el Lord Justice Woolf, miembro de la Corte de Apelaciones, explicó el obstáculo que enfrentaban los recurrentes:

... se enfrentaron con el hecho de que la fiabilidad de la prueba dactilar está hoy tan bien establecida que la única forma en que el Ministerio del Interior podría tener la prueba que alegaban tener (si su cliente tiene la razón) era si alguien dentro del Ministerio del Interior hubiese sido responsable de un comportamiento total y completamente ilegal ${ }^{187}$.

La Corte confiaba tanto en los resultados de la identificación por huellas dactilares latentes que la única posibilidad de error que consideraba era la existencia de una falta administrativa. El fraude por parte de funcionarios de servicios públicos se consideró como algo mucho más probable que un error de los examinadores de huellas dactilares ${ }^{188}$.

En cuanto a otras tecnologías emergentes, hay algunas decisiones que rechazan impugnaciones específicas y más bien superficiales, como sobre el uso de polvo de aluminio para ayudar a detectar y registrar huellas dactilares latentes ${ }^{189}$.

\subsection{Admisibilidad y otras impugnaciones en Australia y Canadá}

Las impugnaciones australianas se asemejan a las experiencias en las otras jurisdicciones analizadas. Se centran principalmente en cuestiones procedimentales ${ }^{190}$, como el uso de huellas dactilares obtenidas cuando el acusado era menor de

185 S. v. United Kingdom (30562/04) (2009) 48 E.H.R.R. 50; Gaughran's Application for Judicial Review, Re, [2015] UKSC 29; R (on the application of GC) v. Commissioner of Police of the Metropolis, [2011] UKSC 21.

${ }_{186} R$ (on the application of YZ) $v$ Secretary of State for the Home Department, [2011] EWHC 205 (Admin); R (on the application of Haedare) v. Secretary of State for the Home Department, [2009] EWHC (Admin) 3444; $R$ (on the application of Shayanth) $v$. Secretary of State for the Home Department, [2009] EWHC 1208 (Admin); AA (Somalia) v Secretary of State for the Home Department, [2006] EWCA Civ 1540; $R$ (on the application of TS) v. Secretary of State for the Home Department, [2010] EWHC 2614 (Admin).

187 The Queen v. The Secretary of State For the Home Department, 1992 WL 12678453. Véase también Patterson (Alexander) v. Nixon, 1960 J.C. 42.

188 Puede ser que dicha postura esté bien fundada si los registros de huellas son completos y de los 10 dedos. Sin embargo, siempre existirá la posibilidad de errores administrativos, como un error en el etiquetado de las muestras.

189 HM Advocate v. Dennison, 1978 S.L.T. (Notas) 79.

190 R. v. Delgado-Guerra; ex parte Attorney-General, [2002] 2 Qd R 384; Director of Public Prosecutions v Morrison, [1993] 1 VR 573 (consentido); Carr v. The Queen (1973) 127 CLR 662; Boski v. Biffin [2015] NSWSC 363; Watkins v. Victoria [2010] VSCA 138, (2010) 27 VR 543; Maguire v. Beaton 
edad ${ }^{191}$ o la legalidad de obtener las huellas de un menor ${ }^{192}$; si se advirtió adecuadamente al imputado ${ }^{193}$; si la divulgación (o la implicación) de la comisión de delitos en el pasado, gracias a la existencia de un registro de huellas dactilares, fue injusto para el acusado ${ }^{194}$; si el jurado podría comparar directamente las huellas dactilares o utilizar las huellas dactilares para sopesar la opinión del examinador ${ }^{195}$; la calificación como testimonio de oídas de las huellas dactilares presentadas en un documento ${ }^{196}$; si las huellas dactilares bastarían como prueba para condenar en casos particulares (como en Parker) ${ }^{197}$; y cuáles serían las instrucciones judiciales apropiadas para el jurado cuando la prueba de huellas dactilares estaba en juego ${ }^{198}$.

Un puñado de apelaciones cuestionaron declaraciones que se referían a la actividad asociada con la sedimentación o la antigüedad de una huella dactilar latente ${ }^{199}$. En Hillstead v. The Queen, el examinador de huellas dactilares declaró que las huellas dactilares encontradas en sangre fueron colocadas simultáneamente con el sangriento asesinato. Este testimonio, presentado sin limitaciones ni explicación alguna, se consideró indebido, principalmente porque ipse dixit traspasó el alcance de los conocimientos jurídicamente reconocidos a los expertos en huellas dactilares ${ }^{200}$. En Regina v $S M R$, la apelación se desestimó a pesar de que el examinador declaró sobre la antigüedad de una huella dactilar latente encontrada en un libro de una biblioteca y que el juez del juicio no direccionó adecuadamente las limitaciones de esta prueba ${ }^{201}$. Incluso en Mickelberg v. The Queen, una serie de decisiones condenatorias erróneas que involucraban graves ilegalidades policiales que tardaron décadas en esclarecerse, la atención se centró en si la huella dactilar latente había sido falsificada o plantada, en lugar de preguntarse si los métodos de identificación de huellas dactilares eran válidos y científicamente fiables ${ }^{202}$.

Las referencias australianas al AFIS tienden a ser tanto recientes como superficia$\operatorname{les}^{203}$.

[2005] NSWSC 1241; Bonder v. Howell [1984] WAR 76; Fullerton v. Commissioner of Police [1984] 1 NSWLR 159; Coxan v Mazey [1981] Tas R 209; Sernack v. McTavish [1971] ALR 441.

191 R. v. Sarlija [2006] ACTCA 22.

192 Police (NSW) v. JC [2016] NSWChC 1.

193 Milner v. Anderson (1982) 42 ACTR 23.

194 R. v. Ahola (No 6) [2013] NSWSC 703.

195 R. v. Lawless [1974] VR 398.

196 Re Pong Su (No 18) [2005] VSC 58.

${ }_{197}$ R. v. Barbera (1972) 1 NSWLR 612 (huellas por fuera del vehículo); .R v. Fitzgerald [2005]

SADC 118; Chabine v. The Queen [2006] NSWCCA 179.

198 Reg. v. O'Callaghan [1976] VR 676, 678; R. v. Moore [1982] Qd R 162.

199 Barr v. The Queen [2004] NTCCA 1; Rv SMR [2002] NSWCCA 258.

200 Hillstead $v$. The Queen [2005] WASCA 116, [50], [52]ff.

201 Contrast R. v. Peel (1999) 2 Qd R 400, 410.

202 Mickelberg $v$. The Queen [2004] WASCA 145.

${ }^{203} R v$ Hillier [2010] ACTSC 33; Rv Graham [2017] ACTSC 267; R. v. Parry [2017] SASCFC 66 (inconsistencias entre los examinadores sobre la suficiencia, basado en diferentes huellas de referencia); R. v. DD [2016] ACTSC 149; Shorrock v Commissioner of Police (NSW) [2014] NSWIRComm 1008; R. v. Millard [2006] ACTSC 56. 
En Canadá, las decisiones que consideraron la admisibilidad se centran en las normas que autorizan la captura y recopilación de la toma de huellas ${ }^{204}$; la toma y permanencia de huellas dactilares de menores de edad ${ }^{205}$; si la recopilación y almacenamiento de huellas dactilares infringió los derechos consagrados en la Carta de Naciones Unidas (después de 1982) ${ }^{206}$; la forma en que se pueden utilizar los registros de huellas dactilares ${ }^{207}$; si se requiere a un examinador de huellas dactilares para que declare en juicios de extradición ${ }^{208}$; la admisibilidad de los registros de huellas dactilares en juicios orales ${ }^{209}$; las posibles consecuencias por no proporcionar huellas dactilares cuando los investigadores las solicitan ${ }^{210}$; y si las huellas dactilares pueden constituir prueba suficiente en material penal conforme a Buckingham ${ }^{211}$. Los tribunales canadienses admitieron declaraciones sobre registros parciales de huellas (es decir, que excluían a algunas personas pero no a todas) para ayudar con la identificación del acusado ${ }^{212}$. El hecho de que un examinador en particular no haya participado en muchos casos o no tenga experiencia examinando, junto con el hecho de que el examinador no haya sido llamado a declarar muy a menudo a tribunales, se tomaban como problemas que podrían afectar el valor de la prueba ${ }^{213}$. Los tribunales canadienses también confirmaron que las confesiones seguían siendo voluntarias aun cuando la policía engańaba a un entrevistado afirmando la existencia de pruebas de ADN y de huellas dactilares que los vinculaban con el delito ${ }^{214}$.

Ha habido impugnaciones exitosas en Canadá, pero una vez más, no están enfocadas en cuestiones epistemológicas, es decir, sobre problemas metodológicos o sobre la fiabilidad. Hubo preocupación acerca de: el perjuicio injusto causado por los registros de huellas dactilares presentados por la Corona que estaban relaciona-

204 R. v. Buckingham, 86 C.C.C. 76 (1943); R. v. Hayward, 118 C.C.C. 365 (1957); R. v. S (AS), 2013 BCPC 373 (un menor); $R . v$. $V u, 2007$ BCPC 344; R. v. Do, 2002 BCSC 1889; R. v. Vu, 2014 BCSC 456; R. v. Liang, 2007 YKTC 18; R. v. Nguyen, 2001 BCSC 1869;

${ }^{205}$ R. v. Jacobsen, 1978 CarswellOnt 1849; F (DD), Re, 1984 CarswellOnt 1571; R. v. N (A) [1977] 2 W.W.R. 577; B. v. B, [1982] 5 W.W.R. 644 (uso de la fuerza); R. v. Lin, 76 W.C.B. (2d) 386 (2008); R. v. S (SA), 150 A.R. 228 (1994).

206 R. v. Le, 2004 BCPC 122; R v Feeney, 1999 CarswellBC 622; Rv Corall, 146 A.R. 202 (1993); R. v. Connors, [1998] 8 W.W.R. 421; R. v. Wu, [2002] O.J. No. 4758; R. v. Colwell, 4 W.C.B. (2d) 30 (1988); R. v. Gale, 35 W.C.B. (2d) 421 (1997); R. v. Davis, 2008 BCPC 266; Rv McKay, 136 A.R. 130 (1992); R. v. Feeney, 2001 BCCA 113;

${ }^{207} R . v$. Delaney, 1964 CarswellBC 1 (el registro se puede usar para probar la identidad al igual que en condenas anteriores).

208 United States v. Francis, 2010 ABCA 353, "las huellas dactilares recolectadas, registradas y conservadas siguiendo el curso ordinario de las actividades policiales, tienen una presunción de confianza en que se basa su incorporación como prueba admisible en esta audiencia de extradición”.

209 R. v. Page, [1989] B.C.W.L.D. 2456.

210 R. v. Wright, [1990] O.J. No. 727.

211 R. v. Keller (1970) 1 CCC (2d) 360.

212 R. v. Gayle, 2013 ONSC 5292; R. v. Carpenter, 2010 BCCA 27.

213 R. v. Gabriel, 2013 QCCS 7034.

214 R. v. Fabas, 2008 BCSC 677; R. v. Tan, 2011 BCSC 334. Esto es menos discutido en los Estados Unidos. 
dos con una investigación anterior ${ }^{215}$; la amplitud de los poderes legislativos en el common law para recopilar y retener huellas dactilares ${ }^{216}$; las violaciones a la Carta de Naciones Unidas ${ }^{217}$; y la caracterización como testimonio de oídas de los informes de huellas dactilares de extranjeros (por ejemplo, certificados del FBI) en los procedimientos de extradición ${ }^{218}$. Una de las impugnaciones reportadas quizás más problemáticas planteaba la cuestión de cómo podían los tribunales confiar en que las tarjetas de registro de huellas dactilares contenían realmente las huellas dactilares del acusado en particular ${ }^{219}$.

Los siguientes casos son indicativos de impugnaciones jurídicas exitosas. En $R$. v. Pressley se admitió la identificación, el único problema era cómo pudo colocarse una huella dactilar en una ventana adyacente al lugar donde se retiró una caja fuerte y cuánto tiempo podría haber estado allí ${ }^{220}$. Los expertos «declararon afirmando que el testimonio sobre las huellas dactilares es infalible y que las huellas dactilares encontradas en el alféizar eran las del apelante y no podían ser de ninguna otra persona ${ }^{221}$. Sin embargo, la Corte confirmó la apelación, sin estar segura acerca de las circunstancias de la antigüedad de la huella. En $R v$ Carey, el recurrente había sido visto saliendo de un callejón, donde se encontraron sus huellas dactilares en vidrios rotos retirados de la ventana de un local adyacente, lo que «no se puede decir que conduzca irremediablemente a la conclusión de ... su culpabilidad» ${ }^{222}$. De manera similar, en $R$. v. O'Keefe, la identificación a través de los registros de la RCMP no fue impugnada, solo su pertinencia en relación a si O'Keefe poseía bienes robados ${ }^{223}$. El Tribunal de Apelaciones de Ontario concluyó que la presencia de las huellas dactilares de O'Keefe en productos robados no probaba sin más la posesión de dichos bienes. Bien pudo haber manipulado los bienes, pero eso no prueba que estuviera en posesión ilegal de ellos. Incluso después de Buckingham, los jueces canadienses continuaron empleando categorías jurídicas e incertidumbres probatorias para moderar el impacto de la identificación mediante huellas dactilares latentes.

Antes de los casos asociados con R. v. Bornyk (discutidos en la sección 6.D), solo algunas de las decisiones hicieron referencia al AFIS, las bases de datos y otras nuevas tecnologías y técnicas. Las pocas decisiones que hacen referencia a los procedimientos y las tecnologías empleados tienden a hacer simples menciones, que en ocasiones incluyen algún pequeño detalle. De los más o menos 20 casos que se refieren al AFIS

215 R. v. Milani, 2016 ONSC 7074.

216 R. v. McLarty, 40 C.C.C. (2d) 72 (1978); R. v. Lewis, [1996] B.C.J. No. 1254; Rv Deo, 2006 BCSC 1704.

217 R. v. Luu, 2001 BCPC 411; R v R (G.M.), 136 N.S.R. (2d) 93 (1994); R. v. Kemp, 2016 NSSC 7 (delay); R. v. Bui, 2006 BCPC 47,

${ }_{218}$ R. v. Yousif, 41 W.C.B. (2d) 306 (1998).

219 R. v. Gauthier, 1 C.R.N.S. 107 (1967).

220 R. v. Pressley [1949] 1 WWR 692

221 Pressley, [22]: «Dos expertos en huellas dactilares ... fueron intensa y largamente interrogados por el abogado del recurrente, pero sus declaraciones se mantuvieron inmutables».

${ }^{222}$ R. v. Carey [1945] 85 CCC6. Carey tenía en su poder un destornillador cuando fue detenido.

223 R. v. O'Keefe [1958] OR 499. 
(o a las bases de datos), ninguno planteó inquietudes sobre los procedimientos, el diseño del sistema o los nuevos riesgos que se originan al buscar entre un gran número de huellas dactilares ${ }^{224}$. Ninguno plantea problemas de validez y transparencia asociados con las bases de datos electrónicas y los algoritmos de búsqueda ${ }^{225}$.

\subsection{Resumen}

Mediante una revisión de casos, este capítulo demuestra lo poco atentos e insensibles que fueron los abogados y las instituciones jurídicas sobre las dimensiones epistemológicas de las pruebas de huellas dactilares latentes. Todos los tribunales asumieron no solo que la prueba dactilar era fiable, sino quizás la forma más fiable de prueba ${ }^{226}$. Desde la segunda década del siglo $\mathrm{xx}$, casi todas las impugnaciones a la prueba de huellas dactilares latentes se dirigían a señalar algún problema de tipo jurídico. Los abogados y los tribunales estaban especialmente preocupados por el cumplimiento de la legislación que permite la recopilación y el uso de las huellas, así como por cuestiones constitucionales y legislativas en los Estados Unidos y Canadá. $\mathrm{Si}$ bien estas respuestas son comprensibles y, en cierto sentido, podrían haber estado entre las respuestas prácticas más efectivas disponibles, privaron de información y conocimientos importantes tanto a los tribunales como a los juzgadores de los hechos y a los profesionales de la ciencia forense. En vez de proporcionar un foro crítico para facilitar la evaluación de la prueba de huellas dactilares latentes, los tribunales alentaron e incluso divinizaron las pruebas dactilares ${ }^{227}$. Su abordaje colocó la fiabilidad de la prueba fuera de toda duda y fomentó muchas impugnaciones de naturaleza jurídico-formal que fueron repetitivas, a veces superficiales y generalmente no exitosas.

Para los observadores externos, llama la atención que pese a la posibilidad de exigir la producción de documentos, de interrogar a los examinadores de huellas dactilares y traer a otros expertos (por ejemplo, investigadores científicos y estadísticos) para refutar a aquellos, los fiscales, los abogados defensores y los jueces parecen no haber estado dispuestos a percibir algunos de los muchos problemas con la prueba de huellas dactilares latentes o tal vez hayan sido incapaces de ello: particularmente la forma en que se producía y presentaba (y seguramente también la forma en que

224 Sin embargo, véase R. v. Pakula, 136 W.C.B. (2d) 285 (2017).

225 R. v. Connors, 49 B.C.L.R. (3d) 376 (1998); Rv Dore, 166 C.C.C. (3d) 225 (2002); R. v. Teskey, 2003 ABPC 225; $R$. v. Qureshi, 2011 ABPC 92; $R v$ Renner, 2008 ABPC 109; $R v$ Ticknovich, 2003 ABQB 854; $R$ c. Cléroux, 2012 QCCQ 9890; R. v.J (J), 2012 ONCJ 133; R. v. Primeau, 2009 ABPC 376; R. v. Gallagher, 2012 BCCA 424; R. v. Mattu, [1996] B.C.J. No. 2182; $R v$ B (DR), 2004 BCPC 144; $R$ v Bird, 2015 SKQB 17; R. v. Kang, 86 W.C.B. (2d) 131 (2009); R. v. Newman, 2013 BCSC 592; R. v. Dueck, 2011 ABPC 53; R. v. McKay, 2010 BCPC 92; $R v S(A S), 2013$ BCPC 373; R. v. Dhudwarr, 102 W.C.B. (2d) 690 (2011);

$226 \mathrm{Al}$ menos hasta que los perfiles de ADN se estabilizaran a mediados de los 90 .

227 Contrástese la deconstrucción jurídica en Jasanoff, 1995. 
era entendida) diariamente en las investigaciones y los procesos judiciales ${ }^{228}$. Es notable que haya tardado un siglo, junto con movimientos esencialmente no jurídicos y cambios significativos en las reglas y procedimientos, antes de que finalmente se abordaran algunos desafíos epistemológicos para su admisibilidad.

\section{NUEVAS REGLAS, "REVOLUCIONES" EN LA ADMISIBILIDAD Y CONDENAS ERRÓNEAS (1975 - 2009)}

Desde mediados de la década de 1970 comenzaron a aparecer una serie de nuevas reglas probatorias y nuevas interpretaciones en nuestras cuatro jurisdicciones. Sin embargo, estas nuevas reglas, junto con sus interpretaciones obligatorias de los tribunales de primera instancia, no cambiaron la forma en que se admitían y presentaban en los procedimientos penales las pruebas de huellas dactilares latentes (y de muchos otros tipos de pruebas científico forenses), comenzando con la introducción de las Federal Rules of Evidence (1975) en los Estados Unidos y continuando con Daubert v. Merrell Dow Pharmaceuticals, Inc (1993) y Kumbo Tire Co.; en Canadá, Ltd v. Carmichael (1998), R. v. Mohan (1994) y R.v.J-LJ (2000); en Australia (desde 1995) la Uniform Evidence Law (UEL); y culminando con una reforma procesal en Inglaterra y Gales ${ }^{229}$. Como veremos, esto es desafortunado y quizás sorprendente, pues muchas de las nuevas reglas de admisibilidad y criterios afines, como los incluidos en Daubert y J-LJ (en Canadá), estaban explícitamente orientados por la fiabilidad de la prueba pericial. En este apartado podemos observar en que grado fue la revolución asociada con Daubert, su encarnación en el procedimiento penal canadiense y, más indirectamente, en el inglés. Curiosamente, ninguno de estos intereses (renovados) en la fiabilidad (jurídica) llevó a excluir la prueba de huellas dactilares latentes o siquiera a exigir una terminología con base más empírica en los informes y las declaraciones de los expertos.

\subsection{Estados Unidos: Las FRE (1975), los perfiles de ADN y Daubert (1993)}

Como hemos visto, las pruebas de huellas dactilares latentes se admitieron y utilizaron rutinariamente en los procesos penales en los Estados Unidos desde principios del siglo xx. La aparición y el uso del criterio «aceptación general» de Frye v. EE. UU. en procedimientos penales, de alguna manera inconsistente desde 1923, parece haber tenido poco impacto perceptible ${ }^{230}$. A medida que el Estado estableció agencias de

228 La credibilidad de un examinador individual (o investigadores) marca la tendencia de la mayoría de las impugnaciones sobre fiabilidad. Véase e.g. R. v. McKechnie (Ian Alexander) [2002] EWCA Crim 3161 and R. v. Zomparelli (Anthony Alberto), 2000 WL 35801961.

${ }_{229}$ R. v. Mohan, [1994] 2 SCR 9; R. v. J-LJ [2000] 2 SCR 600; R. v. DD [2000] 2 SCR 275.

230 Frye v. United States, 293 F. 1013 (D.C. Cir. 1923). Véase también Giannelli, 1980: 6; ChenG y Yoon, 2005: 471; Berger, 2005: S59; Berger, 2003: 1125. 
huellas dactilares, los examinadores de huellas dactilares establecieron rápidamente asociaciones profesionales que desarrollaron reglas, prácticas y estándares basados en supuestos y consensos, en lugar de llevar a cabo investigaciones científicas y evaluaciones formales. La existencia de numerosos departamentos y organizaciones, como la International Association for Identification (IAI, por sus siglas en inglés, fundada en 1915), y la colaboración internacional (como en Jennings), hicieron que fuera relativamente fácil satisfacer a tribunales crédulos de que la identificación mediante las huellas dactilares cumplía con los requisitos de admisibilidad, como la "aceptación general". Para los tribunales, la identificación positiva mediante comparación de huellas dactilares latentes era una cuestión generalmente aceptada entre la comunidad de examinadores de huellas dactilares latentes. De hecho, el enfoque en la aceptación por parte de la comunidad parroquial de examinadores de huellas persiste en algunas jurisdicciones de los EE. UU., aún mucho después de la introducción de criterios de fiabilidad, y continúa brindando inmunidad a los examinadores de huellas dactilares latentes, incluso después de importantes intervenciones por parte de organizaciones científicas autorizadas ${ }^{231}$.

La introducción de las Federal Rules of Evidence (1975), específicamente la regla 702 que regula la prueba pericial (así como la regla 403), junto con su adopción en muchos Estados (complementando el estándar de la aceptación general y otras normas de admisibilidad), poco hizo por cambiar la práctica de los tribunales de Estados Unidos respecto la admisibilidad, antes de la aparición de las demandas colectivas en los años ochenta. De hecho, no fue sino hasta la apelación que en materia civil se presentó en Daubert v. Merrell Dow Pharmaceuticals, Inc. (1993) y en Kumbo Tire Co. v. Carmichael (1998) y la imposición de nuevos criterios de fiabilidad (adoptados rápidamente en la mayoría de los Estados) preocupados por el sometimiento a test, la revisión por pares y la publicación, las tasas y estándares de error, así como por la aceptación general (los cuatro criterios que se conocen como criterios Daubert), que los abogados defensores comenzaron lentamente a cuestionar los procedimientos científico-forenses utilizados en los procedimientos penales, que hasta entonces habían sido inmunes a impugnaciones serias durante más de un siglo ${ }^{232}$. Recién hacia finales del siglo xx, como consecuencia de Daubert, la introducción de los perfiles de ADN, la crítica académica a las ciencias forenses y la exposición de las condenas erróneas a través de los Proyectos Inocencia, los abogados defensores comenzaron a intentar las primeras impugnaciones sofisticadas a la prueba de huellas dactilares latentes. Los casos de US v . Mitchell y US v. Llera-Plaza se encuentran entre los más antiguos y destacados de ello.

La primera impugnación seria post-Daubert a la admisibilidad de la prueba de huellas dactilares latentes fue en la acusación contra Byron Mitchell ${ }^{233}$. El Tribunal

231 United States v. Love, 2011 WL 2173644, 7 (S.D. Cal. 2011); United States v Otero, 849 F. Supp.2d 425, $431 \mathrm{ff}$ (D.N.J. 2012).

232 Daubert v. Merrell Dow Pharmaceuticals, Inc 113 S Ct 2786 (1993); Kumho Tire Co. v. Carmichael 526 US 137 (1999).

233 U.S. v. Mitchell, 365 F.3d 215, 236 (3rd Cir. 2004). Véase también United States v. Mitchell, 145 F.3d 572 (3rd Cir. 1998), United States v Mitchell, 199 F.Supp.2d 262 (E.D. Pa, 2002). La trans- 
de Distrito llevó a cabo «una extensa audiencia Daubert» que duró cinco días, escuchando declaraciones de once expertos y generando un voluminoso registro sobre la admisibilidad de las pruebas de huellas dactilares presentadas por el Estado (y de los expertos presentados por Mitchell) ${ }^{234}$. Analicemos la respuesta que en sede de apelación se dio a dicha impugnación de admisibilidad, enfocada en si la identificación de huellas dactilares latentes satisfacía los criterios de Daubert.

El Tribunal de Apelaciones del Tercer Circuito dividió en dos partes el primer criterio Daubert (el requisito de que las afirmaciones deben ser testeables o haber sido sometidas a test). Primero, las premisas subyacentes de perdurabilidad y unicidad son testeables y han sido sometidas a test. El tribunal aceptó que cada una de estas afirmaciones eran susceptibles de ser sometidas a test. La perdurabilidad de las huellas dactilares fue relativamente fácil de testear, aunque en la «audiencia no se proporcionó mucha prueba sobre el efectivo sometimiento a test de la hipótesis» ${ }^{235}$. La unicidad era más difícil de demostrar. El Tribunal se basó en varias formas diferentes de «test», como la incapacidad de encontrar huellas idénticas y parciales en bases de datos muy grandes, estudios en gemelos idénticos y el hecho de que múltiples agencias de huellas dactilares «no habían encontrado a dos personas diferentes con la misma huella dactilar ${ }^{236}$. La segunda parte del sometimiento a test estaba relacionada con la posibilidad de demostrar la identificación positiva «a partir de huellas dactilares que contengan suficiente cantidad y calidad de detalles» ${ }^{237}$. El Tribunal aceptó que esto podría ser fácil de demostrar en condiciones ideales. El gobierno había realizado una serie de elaborados intentos (incluida una serie de experimentos) para sustentar su posición. Para el Tribunal, estos experimentos fueron metodológicamente débiles, pues no se correspondían con la «identificación positiva ... a partir de huellas dactilares reales» ${ }^{238}$. Al final, se señaló que es la capacidad del examinador para describir los detalles y la suficiencia lo que «rescata []" la identificación de huellas dactilares en los casos. Esto estaba relacionado con el método y con el hecho de que «ninguna agencia estatal ... había encontrado una huella dactilar latente que "coincidiera con dos dedos diferentes de la misma persona o incluso con personas diferentes» ${ }^{239}$. El Tribunal señaló que estaba «reacio» a considerar que el resultado [de este análisis] favorecía al gobierno», pero finalmente se dejó convencer por «una larga historia de test implícitos» en los procedimientos penales a lo largo del siglo XX. «Por otra parte, la susceptibilidad a test» podría abordarse mediante las garantías procesales; más claramente con "la posibilidad de un interrogatorio cruzado significativo» ${ }^{240}$.

cripción del caso Mitchell entregó una base para los argumentos de Llera Plaza.

${ }^{234}$ Las audiencias Daubert son a propósito de la admisibilidad de la prueba pericial.

235 Mitchell, 236.

236 Mitchell, 236

237 Mitchell, 236.

238 Mitchell, 237-238, 227-228. (cursivas en el original). Una parte involucraba comparar unas fracciones de las huellas de referencia (cerca de un 20 a 25\%, también llamadas pseudolatentes) de una gran base de datos, con todas las huellas de la base de datos.

239 Mitchell, 237.

240 Mitchell, 238. 
Respecto la revisión por pares y publicación, el Estado argumentó que la «verificación ... constituye una efectiva revisión por pares». Reconociendo que la revisión por pares no fue independiente (o ciega) y que parecía haber una «regla de unanimidad», el Tribunal consideró que «el paso de la verificación del ACE-V puede no ser una revisión por pares en su mejor forma, pero, en definitiva, el factor de «revisión por pares» de hecho favorece su admisión». En cuanto a las obras escritas, el Tribunal señaló que: «la faceta de la publicación de la revisión por pares no es un factor importante y ni refuerza ni desvirtúa nuestra conclusión de que el factor de revisión por pares favorece la admisión» ${ }^{241}$.

El aparentemente bajo rango de error fue presentado como un factor a favor de la admisión. Enfocándose en los falsos positivos (es decir, en las identificaciones erróneas), el Tribunal decidió que «[a]sumiendo ... que una tasa ha sido sólidamente establecida, seguramente será una tasa de error baja» ${ }^{242}$. Esto situó la confianza en los alegatos del Estado respecto a que: las agencias no habían tenido noticias de coincidencias erróneas en la práctica; los empleados estatales que hacían las pruebas tenían una tasa de error bastante baja en su tarea; y, ninguna de las agencias del Estado (o pruebas con computadora) había cometido errores al encontrar coincidencias cuando se les enviaron las impresiones dactilares de Mitchell con el fin de revisar las pruebas del caso $^{243}$.

La tasa de error ha sido lo suficientemente identificada como para considerar que este factor favorece fuertemente la admisión de la prueba. La tasa de error no ha sido cuantificada precisamente, pero los diversos métodos para estimar la tasa de error sugieren que es muy baja ${ }^{244}$.

En cuanto a los estándares, en ausencia de un sistema de puntos, el enfoque flexible para hacer una identificación significa «que el método del FBI carece de un parámetro significativo de objetividad basado en estándares» ${ }^{245}$. A pesar de los estándares del procedimiento (como el ACE-V) y los estándares terminológicos (como las convenciones de nomenclatura para los puntos de Galton), el Tribunal señaló que:

... estos son insustanciales en comparación con los estándares elaborados y exhaustivamente refinados que se encuentran en muchas disciplinas científicas y técnicas. En tal sentido, encontramos que este factor no favorece la admisión de la prueba ${ }^{246}$.

Finalmente, el Tribunal consideró que la identificación de huellas dactilares «goza de la aceptación general dentro de la comunidad de identificación forense», encontrando respaldo en una decisión reciente del Cuarto Circuito «que se basó en gran medida en la aceptación general para respaldar su admisión» ${ }^{247}$. El Tribunal rechazó, por irrelevante, el argumento de la defensa de que la comparación de las huellas dactilares no era aceptada por la comunidad científica.

\author{
241 Mitchell, 239. \\ 242 Mitchell, 239. \\ 243 Mitchell, 231. \\ 244 Mitchell, 241. \\ 245 Mitchell, 241. \\ 246 Mitchell, 241. \\ 247 Mitchell, 241. Citando a United States v. Crisp, 324 F.3d 261 (4th Cir.2003).
}


En resumen, el Tribunal concluyó que «las pruebas de huellas dactilares presentadas por el Estado aprobaron el examen». El Estado había convencido a los jueces de que había «buenos argumentos» para la opinión de los expertos ${ }^{248}$. La caracterización de la prueba de huellas dactilares como «ciencia» o con alguna otra etiqueta (como «conocimiento técnico») no fue importante, porque después de Kumho, la "[f]iabilidad siguió siendo el principio guía» ${ }^{249}$. Las limitaciones con la identificación mediante huellas dactilares eran entonces problemas que podían resolverse mediante «el sistema adversarial». La siguiente proposición de Daubert fue invocada con su aprobación:

Un intenso interrogatorio cruzado, la presentación de pruebas en contra y las instrucciones judiciales cuidadosas al jurado sobre la carga de la prueba, son los medios tradicionales y apropiados para atacar la prueba débil pero admisible ${ }^{250}$.

El Tribunal de Apelaciones explicó que no estaba introduciendo una «regla categórica de que las pruebas de huellas dactilares latentes eran admisibles» en el Tercer Circuito, pero que esperaba que su detallada resolución brindara una "guía sólida» al respecto. Ello no exigía «extensas audiencias Daubert en todos los casos»" ${ }^{251}$.

Hubo además otras cuestiones tratadas en la apelación. El juez del juicio había decidido que los expertos convocados por la defensa no podían testificar sobre si las pruebas de huellas dactilares latentes eran o no una ciencia ${ }^{252}$. Su testimonio fue restringido a las prácticas y su fiabilidad. La decisión fue considerada por la defensa como una decisión de exclusión de prueba, pero el Tribunal de Apelaciones consideró que se trataba de una reacción exagerada de la defensa. Además, el juez del juicio había considerado como hechos notorios la perdurabilidad y la unicidad de las huellas dactilares. El Tribunal de Apelaciones no los consideró como «hechos» cuya "fiabilidad no pudiera ser cuestionada razonablemente», como se indica en los registros, sino que son áreas «sujetas a una disputa razonable» ${ }^{253}$. En consecuencia, el juez del juicio no debería haberlos declarado como hechos notorios o instruido al jurado para que aceptase estas afirmaciones como hechos. Estas instrucciones del juez al jurado, en un juicio oral donde la fiabilidad de la prueba de huellas dactilares latentes estaba en cuestión, se consideraron como un "harmless erron (error inocuo)" 254 . Finalmente, después de la condena de Mitchell, y presumiblemente en respuesta a esta y otras impugnaciones de admisibilidad, el FBI emitió una convocatoria (o solicitud) para que se realizaran «estudios de validación del sistema de huellas dactilares». Mitchell afirmó que esto violaba las obligaciones del estado establecidas en Brady v.

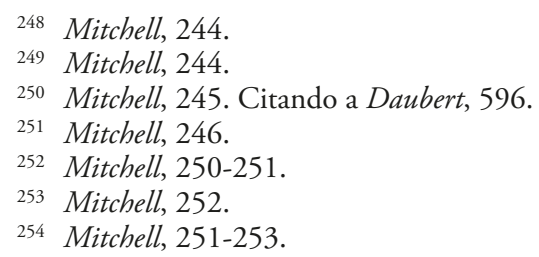


Maryland, al omitir información material y favorable a la defensa con la cual podría haber impugnado a los testigos expertos del Estado ${ }^{255}$. La Corte discrepó.

Otra impugnación sobresaliente la encontramos en US v. Llera Plaza ${ }^{256}$. Hay dos decisiones en Llera-plaza. El juez Pollak inicialmente se pronunció a favor de la exclusión, impidiendo que el gobierno de los Estados Unidos introdujera pruebas de huellas dactilares latentes. Tras un recurso de reconsideración y tres días adicionales de audiencias, Pollak se retractó y declaró que la prueba de huellas dactilares latentes era admisible. Antes de su revocación, Llera Plaza I era la más destacada de las decisiones modernas. La primera decisión concluyó que la prueba de huellas dactilares latentes solo cumplía parcialmente uno de los criterios Daubert. Incluso ese criterio, el de «aceptación general», no se cumplía completamente porque la «comunidad de expertos en huellas dactilares» no eran "considerados como 'comunidad científica'». 257 $\mathrm{Al}$ reconsiderarlo y tratar la comparación mediante huellas dactilares latentes como conocimiento técnico (después de Kumho) y no como una ciencia, Pollak quedó conforme con que la prueba era lo suficientemente fiable para ser presentada ante un jurado ${ }^{258}$. Incluso después de revertir su decisión, Pollak lamentó que ni la «verificación» (del ACE-V), ni «un siglo de juicios hayan constituido una forma de test 'adversariales' que satisficieran los criterios Daubert». ${ }^{259}$ Esto se consideró desafortunado porque un test genuino "claramente ayudaría a medir la fiabilidad del ACE-V» ${ }^{260}$.

Después de la nueva audiencia, en la que el gobierno puso énfasis en las pruebas de aptitud de los examinadores de huellas dactilares y en que el criterio Daubert era «flexible», Pollak se convenció de que las pruebas de huellas dactilares latentes eran admisibles como una disciplina "técnica» ${ }^{261}$. Se remitió para ello a las pruebas de aptitud rutinarias del FBI y otros examinadores de huellas dactilares (con un «índice de error de poco menos del 1\%»), demostrando "un nivel aceptable de competencia», junto con el hecho de que no se conocían «identificaciones erróneas atribuibles a examinadores del FBI» ${ }^{262}$. Admitiendo que esa "ausencia de conocimiento» no prueba la ausencia de errores, "nada en los registros sugiere que lo contrario es cierto" ${ }^{263}$. En la segunda resolución, Pollak se refirió distendidamente sobre la extensa historia de admisión jurídica y confianza en esta prueba: «Los tribunales ingleses y estadoun-

255 Brady v. Maryland, 373 US 83 (1963).

256 U.S. v. Llera Plaza, 188 F.Supp.2d 549 (E.D.Pa 2002).

257 Llera Plaza, 563.

258 Esta decisión se basa incómodamente en la aproximación a dicha nomenclatura utilizada en Mitchell. Véase también United States v. Haavard 117 F Supp 2d 848 (SD Ind 2000). Y en general, Thomas Gieryn, Cultural boundaries of science (Chicago, Chicago University Press, 1999).

259 Llera Plaza, 564, 571.

260 Llera Plaza, 571-572. Este enfoque es bastante diferente al enfoque de Mitchell, publicado en 2004.

261 Llera Plaza, 562.

262 Llera Plaza, 556, 565-6, 573 (cursivas como en el original). Curiosamente, el proveedor comercial de las evaluaciones de aptitud del FBI fue después criticado por hacer estas pruebas demasiado fáciles. Informe del PCAST, 57, n133.

263 Llera Plaza, 566. 
idenses han aceptado la prueba de dactilar durante casi un siglo» ${ }^{264}$. Se remitió a los casos ingleses Castleton y R. v. Buckley (1999), así como a las primeras decisiones estadounidenses, como Jennings ${ }^{265}$. Lo mismo hizo respecto a la historia temprana de los estudios sobre huellas dactilares latentes, con referencias a las contribuciones de Francis Galton (1822-1911), Edward Henry (1850-1931), Sir William Herschel (1833-1917) y, especialmente, de Henry Faulds (1843-1940) ${ }^{266}$. Pollak también puso énfasis, y aparentemente su confianza, en que los examinadores británicos de huellas dactilares utilizan un procedimiento «esencialmente idéntico» al empleado por el FBI (es decir, ACE-V), junto con el hecho de que las interpretaciones del FBI también eran admisibles en juicios ingleses ${ }^{267}$. Explicó:

... las conclusiones que, sujetas a una cuidadosa supervisión judicial, son consideradas suficientemente fiables en Inglaterra, deberían ser también consideradas lo suficientemente fiables en los tribunales federales de los Estados Unidos ${ }^{268}$.

Este último punto es curioso dado que la jurisprudencia inglesa de admisibilidad no impone un estándar de fiabilidad formal (o criterios Daubert) para la admisión la prueba pericial en procedimientos penales. De hecho, los criterios de admisibilidad para la prueba pericial en los procedimientos penales en Inglaterra fueron descritos como «laissez faire» por la Law Comission de Inglaterra y Gales ${ }^{269}$.

Estos juicios orales y apelaciones posteriores a Daubert representan los primeros desafíos metodológicamente sofisticados a la prueba dactilar durante su larga historia jurídica. Son inusuales porque la defensa contrató no solo a individuos con experiencia en la comparación de huellas dactilares latentes, sino también a individuos con una variedad de perspectivas científicas, técnicas, sociológicas e históricas que se movilizaron para cuestionar el estatus científico y la fiabilidad de la comparación mediante huellas dactilares latentes en genera $^{270}$.

264 Llera Plaza, 572.

265 R. v. Buckley (1999) 163 JP 561, discutido más adelante.

266 Llera Plaza, $561 \mathrm{ff}$.

267 Llera Plaza, 575-576.

268 Llera Plaza, 576.

269 Law Commission of England and Wales, Expert Evidence in Criminal Proceedings in England and Wales, 34 Law Com. Report No. 325 (HMSO, 2011) 3, 4, 5, 16.

270 La única otra jurisdicción donde han aparecido estos meta-peritos es en el caso Bornyk en Canadá (discutido más adelante); donde uno de los peritos de la defensa de Mitchell declaró junto con un científico de la RCMP. Fuera de los EE.UU., el uso de los expertos por la defensa es poco común y traer a examinadores no-dactilares para declarar en juicio oral es excepcional. Curiosamente, los tribunales en los EE.UU. han tenido opiniones divididas sobre si aceptar o no las declaraciones de estos examinadores no-dactilares en los casos. Véase la discusión en Lynch y Cole, 2005: 269; Cole, 2009: 121. 
4.2. Inglaterra y Gales: La Comisión Real de Runciman, $R v$ Buckley (1999), el Servicio de Ciencias Forenses, las Criminal Procedure Rules, las Crimiminal Practice Directions y los informes forenses simplificados

El sistema de justicia penal de Inglaterra y Gales, y especialmente sus instituciones de ciencias forenses, fue fuertemente sacudido por una serie de errores judiciales cometidos en casos por ataques del IRA en los años 70 y 80. Los famosos Seis de Birmingham, los cuatro de Guildford y los siete de Maguire fueron todos condenados, en parte, sobre la base de pruebas científicas forenses erradas ${ }^{271}$. Entre los problemas se destacaron las pruebas forenses utilizadas para probar el manejo de explosivos. A raíz de estos errores de gran repercusión mediática, May y Runciman llevaron a cabo investigaciones públicas. Entre las recomendaciones de la Comisión Real de Justicia Penal de Runciman se encuentra la necesidad de contar con estándares, garantías de calidad y acreditación, y exigir estudios en ciencias a los científicos forenses. La Comisión recomendó la creación de un Consejo Asesor en Ciencias Forenses, lo que se materializó más de una década después cuando se privatizó la provisión de servicios en ciencias forenses, bajo la forma de un Ente Regulador de Ciencias Forenses (Forensic Science Regulator, FSR, por sus siglas en inglés) ${ }^{272}$. Además, la Comisión Real instó a la creación de Comisiones de Revisión de Casos Penales en Inglaterra, Gales y Escocia, para proporcionar un medio adicional de investigación y poder volver a revisar determinadas condenas.

Poco después de estas investigaciones públicas, se reestructuró el Servicio de Ciencias Forenses (Forensic Science Service, FSS, por sus siglas en inglés), el principal proveedor de prueba científica forense hasta entonces. Se convirtió en un organismo público, y en varias otras encarnaciones institucionales, que cobraba tarifas por sus servicios. Los altos costos de funcionamiento del FSS se utilizaron como fundamento para justificar su cierre en 2012. El cierre dio lugar a la privatización y a una mayor dependencia en los mecanismos del mercado para la prestación de servicios forenses, acompañado con cierto nivel de consolidación de los servicios de ciencia forense dentro de los departamentos de policía ${ }^{273}$. Justo antes de que se cerrara el FSS, y tal vez previendo el auge de un amplio mercado competitivo para los servicios de ciencia forense, el gobierno creó un Ente Regulador de Ciencia Forense (Forensic Science Regulator, FSR, por sus siglas en inglés) en 2008, para brindar asesoramiento y orientación sobre pruebas con fundamento en las ciencias forenses. Este reciente Ente ha proporcionado una cantidad sustancial de informes que son consistentes con los tipos de problemas y preocupaciones planteadas por los informes discutidos en el apartado $6^{274}$.

271 Walker y Starmer, 1999; Nobles y Schiff, 2000. Casos recientes más problemáticos incluyen R. v. George (Barry) [2007] EWCA Crim 2722 y R. v. Hoey [2007] NICC 49.

272 Véase LAWLESS, 2016.

273 RoBERTs, 2017: 502.

274 Hoy en día las guías del FSR son meramente consultivas. 
Poco se dijo sobre la prueba dactilar, o cualquier otro tipo de ciencia forense, en la Comisión Real de Runciman. La apelación en $R$. v. Buckley, resuelta apenas unos años después de la Comisión Real, nos entrega un panorama útil sobre la postura dominante en Inglaterra acerca de la prueba de huellas dactilares latentes. Curiosamente, analizando el panorama histórico proporcionado por el tribunal, no hay una conciencia de los problemas y ninguna referencia a la crisis en las ciencias forenses que llevaron a la investigación pública de Runciman.

La huella dactilar de Buckley fue encontrada en bienes robados durante un robo calificado ${ }^{275}$. Sin ninguna explicación, la defensa abandonó el recurso de apelación. Sin embargo, el Tribunal de Apelaciones decidió proporcionar un panorama general del estado de las pruebas de huellas dactilares latentes, basándose en información entregada por el abogado recurrente sobre la historia del uso de pruebas dactilares en los tribunales ingleses. Como veremos, la mayor parte de esa historia se refiere a la introducción, aceptación y abandono del sistema de puntos específicos. El Tribunal se esfuerza por presentar la comparación mediante huellas dactilares como un procedimiento incuestionablemente fiable, pero la variedad de respuestas (inexplicablemente inconsistentes) de la comunidad de huellas dactilares, y sus responsables, amenaza con socavar este trato favorable.

El Tribunal comienza su análisis apuntando la inconsistencia en el enfoque histórico (y de hecho reciente) de las pruebas de huellas dactilares, en particular respecto del sistema de puntos. En casos recientes se ha excluido una identificación basada en 10 puntos de similitud y se han admitido identificaciones basadas en 12 puntos. Esta «inconsistencia» parece haber motivado que el tribunal analizara el tema incluso después de que se declarara abandonada la apelación. El Tribunal señaló que la identificación por huellas dactilares latentes se basa en que «desde hace tiempo se sabe que los patrones de huellas dactilares varían de persona a persona y que dichos patrones son únicos e invariables a lo largo de la vida» ${ }^{276}$. Su estudio comienza con Castleton, cuando no "había criterios o estándares establecidos". Posteriormente y de manera gradual «se aceptó que una vez que se pudieran identificar 12 características o puntos similares, se podía probar la identidad de alguien más allá de toda duda» ${ }^{277}$. En 1924, la nueva Scotland Yard introdujo un estándar de 16 puntos basada en la investigación de Alphonse Bertillon (1853-1914). Este nuevo estándar, que recientemente se ha demostrado que se basó en huellas fabricadas y por tanto sus premisas son falsas, no fue utilizado por todas las fuerzas policiales en el Reino Unido.

En 1953, el Ministerio Público, representantes del Ministerio del Interior y varias fuerzas policiales adoptaron un Estándar Nacional de Huellas Dactilares que exigía 16 puntos de similitud para realizar una identificación. Simultáneamente, se estab-

275 R. v. Buckley (1999) 163 JP 561. Hubo otras pruebas en el caso, aunque Buckley ofreció una explicación para su huella dactilar consistente en haberla dejado después del robo.

276 Buckley, 5.

277 Buckley, 5. El fundamento sobre el cual esto fue aceptado o si hubo algún fundamento empírico, fue evitado. 
leció una Conferencia Nacional de Expertos en Huellas Dactilares para monitorear dicho estándar. Este estándar se modificó posteriormente para que cuando una escena produjera una huella latente con 16 puntos de coincidencia, «cualquier otra marca en la misma escena podría ser usada si se identificaban al menos diez puntos de coincidencia» ${ }^{278}$. Según el Tribunal, con el tiempo hubo consciencia de que:

bastante menos que 16 puntos de coincidencia pueden permitir la identificación más allá de cualquier duda. Algunos expertos sugirieron que ocho puntos proporcionarían completa seguridad. Otros sostuvieron que no debería haber ningún estándar numérico. Se nos ha señalado, y así lo reconocemos, que otros países admiten la identificación mediante 12, 10 u 8 características o puntos de similitud y en algunos países el sistema numérico se ha abandonado ${ }^{279}$.

Según el Tribunal, en una conferencia en 1983 parece haberse acordado un estándar de 12 puntos (nuevamente) ${ }^{280}$. Quienes asistieron a la conferencia admitieron que «en raras ocasiones una identificación quedará por debajo del estándar de 12 puntos, pero si la prueba dactilar es de tanta importancia en el caso se debería ante el Tribunal» ${ }^{281}$. En tales «extraordinariamente raros casos» la prueba debe ser presentada «solo por un experto de alto nivel y con alta experiencia»" ${ }^{282}$. El nuevo estándar parece haber sido respaldado por Magistrado Presidente en $R$. $v$. Charles (1998) y por el Otton y otros en R. v. Giles (1988) ${ }^{283}$.

En 1988, interesantemente, el Ministerio del Interior y la Asociación de Jefes de Policía encargaron a dos científicos que revisaran los estándares vigentes ${ }^{284}$. El informe concluyó que "no había una base científica, lógica o estadística para conservar un estándar numérico» ${ }^{285}$. Esto llevó a la policía a abandonar formalmente los estándares numéricos, a tratar de establecer "procedimientos y protocolos claros» y a desarrollar sistemas nacionales de capacitación, gestión y auditoría. La Corte en Buckley describió este proceso como «un excelente trabajo de la policía y los expertos en huellas dactilares».

En cuanto a la admisibilidad, la prueba de huellas dactilares «es admisible ... si tiende a demostrar la culpabilidad del acusado». Además, puede «servir incluso si hay solo pocas características de coincidencia, pero en tal caso tendrán menor valor probatorio» ${ }^{286}$. Sobre la base de su análisis histórico y el «estado actual de conocimiento y experiencia en relación con las huellas dactilares», la Corte ofreció la siguiente guía:

278 Buckley, 5-6.

279 Buckley, 6.

280 Estos estándares no se basan en ninguna prueba o estudio empírico, sino en el consenso.

281 Buckley, 6.

282 Buckley, 6.

283 Casos no publicados, citados en Buckley.

284 Véase Evett y Williams, 1996: 49.

285 Buckely, 7.

286 Buckley, 8. Esta declaración parece permitir la admisión de interpretaciones que reporten similitudes que no equivalen a una identificación positiva. Históricamente, las asociaciones profesionales, como el IAI, habían prohibido tales testimonios. Para la mayoría de los examinadores de huellas dactilares no era nada: identificación, exclusión o insuficiencia (y, por lo tanto, no se puede excluir). 
Si hay menos de ocho características similares es altamente improbable que un juez ejerza su discrecionalidad para admitir dicha prueba y, salvo en circunstancias totalmente excepcionales, la acusación no debe tratar de introducir dicha prueba. Si hay ocho o más características similares, un juez puede o no ejercer su discrecionalidad a favor de admitir la prueba. La forma en que se ejerce la discrecionalidad judicial dependerá de las circunstancias del caso, incluyendo en particular:

(i) la experiencia y pericia del experto;

(ii) el número de características similares;

(iii) si existen características disímiles;

(iv) el tamańo de la huella en la que se basa la comparación, ya que el mismo número de características similares puede ser más convincente en un fragmento de la huella que en una impresión dactilar completa; $y$

(v) la calidad y claridad de la impresión dactilar dejada en el objeto, lo que puede implicar, por ejemplo, considerar posibles heridas en la persona que dejó la huella, así como factores como manchas o contaminación.

En todos los casos en los que se admitan pruebas de huellas dactilares, será generalmente necesario, al igual que con todas las pruebas periciales, que el juez advierta al jurado que se trata solo de una prueba de opinión y que la opinión del perito no es concluyente; por tanto, corresponde al jurado determinar si el acusado es culpable o no a la luz de todas las pruebas.

Una cuestión notable en Buckley es la aparente incapacidad (o falta de voluntad) del Tribunal de Apelaciones para reflexionar sobre la falta de apoyo científico independiente, la arbitrariedad de los diversos sistemas de puntos y la recepción poco crítica de la prueba dactilar durante todo el siglo xx. A la luz de la Conferencia de 1983, el estándar de 1953 es caracterizado por ser «indefendible lógicamente» ${ }^{287}$. El Tribunal reconoció que «lógico o no, ese sistema funcionó durante muchos años» sin tener en cuenta lo que esto podría significar para la acusación y las condenas o la eficacia de los procesos penales. Al final, todo se muestra como un avance y el trabajo de la policía y las comunidades de huellas dactilares es caracterizado como «excelente».

Más recientemente, en 2011, la Law Commission de Inglaterra y Gales publicó un informe sobre la prueba pericial en los procedimientos penales. El informe final criticó el estándar de admisibilidad prevaleciente como «laissez faire» y recomendó la introducción de un umbral de fiabilidad y una serie de criterios influenciados por Daubert. La Comisión también expresó sus dudas sobre la capacidad de las garantías procesales para permitir identificar y expresar los problemas de la prueba científica forense. A pesar de estas preocupaciones, las recomendaciones de la Comisión incorporadas en proyectos de ley, no fueron respaldadas por el gobierno; en gran medida debido a los altos costos involucrados y considerando que eran tiempos de recesión mundial ${ }^{288}$.

La manifestación más reciente de cierto nivel de ansiedad judicial sobre las ciencias forenses, tal vez motivada por la desaparición del respetado FSS junto con el crítico informe de la Comisión Legislativa, es la modificación de las Reglas de Procedimiento Penal [Criminal Procedure Rules (CrimPR)] y las Instrucciones para la

287 Sin embargo, no se explica por qué debería preferirse la posición de 1983.

288 Se consideró el costo de volver a entrenar a los jueces y abogados. 
Práctica Penal [Criminal Practice Directions (CrimPD)]. En respuesta a la incapacidad del gobierno de incorporar la necesidad de la fiabilidad en una norma particular, los jueces de tribunales superiores han incorporado la necesidad de la fiabilidad en las normas que regulan el procedimiento penal, la conducta de los peritos y el contenido de sus informes ${ }^{289}$. Las versiones reformadas de las CrimPR y CrimPD están obviamente influenciadas por los proyectos de ley promovidos en el informe de la Comisión Legislativa. Ponen un énfasis explícito en la fiabilidad, refiriéndose expresamente al testeo y la validación ${ }^{290}$. Aún no se ha resuelto si estas normas de procedimiento son realmente parte de las normas sobre admisibilidad. Junto con las guías preparadas por la FSR, aún no han conducido a la exclusión o cualificación de muchas pruebas científicas forenses ${ }^{291}$.

Irónicamente, en la misma época en que la Comisión Legislativa recomendaba la necesidad de que los abogados y los jueces volcaran su atención hacia criterios de admisibilidad basados en la fiabilidad, la FSR estaba introduciendo guías científicas para la práctica y la presentación de informes de pruebas científico-forenses (después de la desaparición del FSS), los jueces empezaron a formular requisitos potencialmente onerosos en virtud de las CrimPR y CrimPD, el Ministerio de Justicia introdujo los informes forenses simplificados (streamlined forensic reporting, SFR, por sus siglas en inglés) como parte de su iniciativa Swift and Sure Justice ${ }^{292}$. El SFR es un conjunto de procedimientos que se aplica a un grupo determinado de ciencias forenses (incluida la prueba de huellas dactilares latentes), que le permite al Estado entregar una conclusión simple y libre de calificativos (por ejemplo, «la huella dactilar identifica a John Smith»). El SFR exime a estos «informes» de las obligaciones de los informes normales, es decir, la necesidad de explicar lo que se hizo, demostrar su fiabilidad, identificar sus limitaciones, incertidumbres, sus tasas de error, etc., requeridas para cumplir con las reformadas CrimPR y CrimPD. En cambio, se presume que los resultados son precisos y los acusados deben identificar «problemas reales» con el resultado entregado, como requisito para que el Estado esté obligado a responder abordando los problemas específicos planteados por el acusado. El SFR fue introducido para mejorar la eficiencia y, especialmente, para reducir el número de impugnaciones supuestamente poco meritorias a la prueba científico forense ${ }^{293}$.

289 Estos se basaron en decisiones anteriores, como en «Ikarian Reefer» (1993) 20 FSR 563, 565566; R. v. Harris, Rock, Cherry \& Faulder [2005] EWCA Crim 1980, [271]ff; R. v. Bowman [2006] EWCA Crim 417, [174]fff.

290 Véase, e.g., CrimPR 19.4(e), (h), (j), CrimPD 19A.5(a), (c) y 19A.6.

291 Véase WARD, 2013 y STOCKDALE y JaCkson, 2016: 344.

292 Ministry of Justice, Swift and Sure Justice: The Government's Plans for Reform of the Criminal Justice System (2012). Véase también National Streamlined Forensic Reporting Guidance, Section 2 - SFR Guidelines for Providers of Forensic Science and a Practical Step Guide (2015) disponible en https:// www.cps.gov.uk/legal-guidance/streamlined-forensic-reporting-guidance-and-toolkit; O. SALLAVACI, 2016: 235; Edmond, Piasecki y Carr, 2019.

293 Esta impresión, de que los dólares de los contribuyentes se estaban gastando en impugnaciones falaces, podría contrastarse con la prueba presentada en este ensayo. 
Bajo el SFR, la prueba de huellas dactilares no solo se trata como fiable, sino como presuntamente correcta ${ }^{294}$.

\subsection{Canadá: R. v. Mohan, R. v. Abbey (y White Burgess) y condenas erróneas (por ejemplo, Re Truscott y las investigaciones de Kaufman y Goudge)}

A partir del cambio de milenio, los tribunales superiores de Canadá comenzaron a adoptar el interés de sus vecinos estadounidenses por la fiabilidad, complementando con los criterios Daubert las reglas de admisibilidad del common law canadiense y el caso destacado R. v. Mohan.

La Corte Suprema de Canadá, reafirmando el common law justo después de que Daubert fuera dictado en Mohan, explicó que la admisibilidad de la prueba pericial estaba supeditada a: a) su relevancia; b) la necesidad de asistir al juzgador de los hechos; c) la ausencia de cualquier norma de exclusión; y d) un experto debidamente calificado. En una decisión que no hace referencia a Daubert, el único rol de la fiabilidad era fomentar la exclusión "cuando existe el peligro de que [la prueba pericial] se utilice incorrectamente, distorsione el proceso de determinación de los hechos o confunda al jurado» ${ }^{295}$. La Corte, especialmente preocupada por los nuevos tipos de prueba, insistió en que la «prueba pericial que presente una teoría o técnica científica novedosa» debe ser "sometida a un escrutinio especial para determinar si cumple con un umbral básico de fiabilidad» ${ }^{296}$.

Una preocupación más persistente por la fiabilidad surgió gracias a una serie de decisiones y revisiones penales por condenas erróneas a lo largo de aproximadamente una década ${ }^{297}$. En J-LJ, DD y Trochym, la Corte se refirió de manera aprobatoria a Daubert o expresamente avaló la necesidad de la fiabilidad de todas las pruebas periciales como condición previa para su admisión. La Corte Suprema respaldó los criterios de Dauberty la importancia de no dejar todos los problemas de la prueba pericial hasta la etapa de valoración de la prueba ${ }^{298}$. En $J-L J$, el magistrado Binnie llamó la atención sobre la necesidad de que los expertos proporcionen «los criterios científicos necesarios para probar la exactitud de sus conclusiones». De potencial importancia para las pruebas de huellas dactilares y otros antiguos procedimientos científico forenses, la Corte insistió en que «la admisibilidad de la prueba pericial no es una cuestión que se pueda establecer mediante precedentes» ${ }^{299}$. En Trochym, la mayoría de los magistrados describieron los criterios Daubert como «el establecimiento de un marco para evaluar la fiabilidad de las nuevas ciencias y, en consecuencia, su admisibilidad ante el tribunal». Al mismo tiempo, la Corte ofreció una mirada más histórica

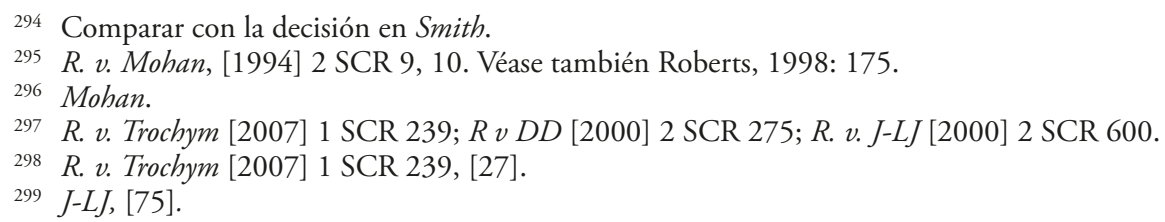


de la prueba científica, que expandió el enfoque principal de Mohan más allá de las «nuevas ciencias». El magistrado Deschamps explicó que la admisibilidad no estaba "congelada en el tiempo»"

Más recientemente, la jurisprudencia canadiense se ha explicado con autoridad sobre la admisibilidad en White Burgess v. Abbott and Halliburton Co. Ltd., una apelación que se refiere sustancialmente al sesgo de los peritos en los procedimientos civiles $^{301}$. El magistrado Cromwell, redactor de la decisión de la Corte Suprema, señala que «en los últimos 20 años más o menos» la Corte «ha endurecido progresivamente sus reglas de admisibilidad y mejorado la función de filtro que tiene el juez» ${ }^{302}$. Este «endurecimiento» tiene la intención de filtrar las pruebas que no «justificaban el riesgo de confusión, el tiempo y los gastos que podían resultar de su admisión” ${ }^{303}$. Hubo una especial preocupación por la deferencia del jurado a los expertos y que su atribución de mucho valor probatorio a ese tipo de pruebas. White Burgess reiteró los cuatro criterios de Mohan, haciendo también hincapié en un segundo "componente»: «el importante papel de los jueces de control al valorar si la prueba pericial, que de otra manera sería admisible, debe ser excluida porque su efecto perjudicial sobrepasa su valor probatorio». Esto se definió como una discrecionalidad residual basada, según R. v. Abbey, «en un análisis de costo-beneficio» ${ }^{304}$. El magistrado Cromwell explicó:

En el segundo paso de control discrecional, el juez pondera los riesgos y beneficios potenciales de admitir la prueba para decidir si los beneficios potenciales justifican los riesgos. El ejercicio de ponderación se ha explicado de varias maneras. En Mohan, Sopinka habló del «factor de fiabilidad versus el de sus consecuencias», mientras que en $J$. $-L J$, Binnie habló de que «la relevancia, la fiabilidad y la necesidad» se "ponderan con los contrapesos del consumo de tiempo, los prejuicios y la confusión». Doherty lo resumió bien en Abbey, afirmando que el «juez del juicio debe decidir si la prueba pericial, que cumple con los requisitos previos de admisibilidad es lo suficientemente beneficiosa para el juicio oral como para justificar su admisión, a pesar del daño potencial que puede derivarse de la admisión de la prueba pericial» ${ }^{305}$.

La Corte llamó la atención sobre el «deber del perito en tribunales» y explicó que este deber, y la expectativa de que el perito sea independiente e imparcial, son cuestiones de admisibilidad ${ }^{306}$. Sin embargo, respecto al tema de la imparcialidad de los peritos, la Corte explicó que las expectativas estarán generalmente satisfechas en la medida en que los peritos reconozcan un «deber primario ante el tribunal» y sean "capaces y estén dispuestos a cumplirlo» 307.

Una serie de investigaciones públicas, que comienzan con el informe de Kaufman sobre Guy Paul Morin, continuando con la investigación de Goudge sobre patologías forenses pediátricas, la revisión de la condena de Truscott realizada por el Tribunal

\footnotetext{
300 Trochym, [31].

301 White Burgess v. Abbott and Halliburton Co Ltd [2015] 2 SCR 182.

302 White Burgess, 189, 194.

303 White Burgess, 194.

304 White Burgess, 196; R. v. Abbey 2009 ONCA 624.

305 White Burgess, 197. (referencias omitidas)

306 White Burgess, 201.

307 White Burgess, 206. Desde aquí el tema de los prejuicios es para la contraparte.
} 
de Apelaciones de Ontario y que culminan con un informe sobre el uso indebido de pruebas toxicológicas en el Hospital Motherisk, atrajeron la atención pública hacia problemas relacionados con la ciencia forense y la medicina forense, mientras los jueces canadienses desarrollaron investigaciones bien financiadas que expusieron problemas endémicos al respecto ${ }^{308}$. Aunque llamaron poderosamente la atención mientras duraron las investigaciones, los distintos informes no han sido muy influyentes, ni siquiera notorios, en el control de admisibilidad en los ańos posteriores a su publicación. Las lecciones aprendidas no se han extendido a la práctica jurídica ni se han extendido más allá del ámbito frecuentemente limitado de la investigación particular y sus campos de trabajo (por ejemplo, la patología forense o la toxicología) ${ }^{309}$.

A pesar del sólido liderazgo de los tribunales superiores de justicia, los tribunales de apelaciones (y, por extensión, los jueces de control) han experimentado dificultades para excluir pruebas de opinión especulativas o para aplicar rigurosamente los criterios de fiabilidad a la prueba pericial ofrecida por el Estado; particularmente en casos en que los criterios no se consideraron adecuados ${ }^{310}$. Los jueces de control y de apelación canadienses se han esforzado por cumplir con los estándares de fiabilidad establecidos por su propia Corte Suprema ${ }^{311}$. No hubo impugnaciones serias a la prueba de huellas dactilares latentes presentada por la RCMP, hasta que un juez comenzó a hacer preguntas en Bornyk, como se analizará más adelante.

\subsection{Australia: Chamberlain (y Splatt), la UEL y más de lo mismo}

Ha habido muy pocas impugnaciones sobre la fiabilidad de las pruebas de huellas dactilares latentes en Australia desde Parker ${ }^{312}$. A pesar de la prohibición en Parker, los examinadores de huellas dactilares han continuado declarado rutinariamente en términos categóricos y han basado su prueba en el hecho de la unicidad de las huellas. La introducción de nuevas reglas probatorias, como la Uniform Evidence Law (UEL) de 1995, que incluye un estándar de admisibilidad para la prueba pericial basada en el modelo de la regla 702 de las FRE estadounidenses (1975), no ha tenido un impacto significativo en la prueba dactilar latente u otras pruebas científico-forenses.

308 J. Beaman, Report of the Motherisk Commission, Harmful Impacts: The Reliance on Hair Testing in Child Protection (Toronto, Province of Ontario, 2018); S. Goudge, Inquiry into Pediatric Forensic Pathology in Ontario (Toronto, Queen's Printer, 2008); P. LeSage, Report of the Commission of Inquiry into Certain Aspects of the Trial and Conviction of James Driskell (Winnipeg, Province of Manitoba, 2007); F. Kaufman, Report of the Kaufman Commission on Proceedings Involving Guy Paul Morin (Toronto, Province of Ontario, 1998). Véase también Re Truscott [2007] ONCA 575.

309 Véase Cunliffe y Edmond, 2018.

310 Véase e.g. R. v. Abbey 2009 ONCA 624; y para las discusiones, Edmond y RoAch, 2011: 343. Y, más recientemente $R . v$. Abbey, 2017 ONCA 640.

311 Véase e.g. R. v. Aitken [2012] BCCA 134, donde la Corte de Apelaciones admitió los análisis forenses realizados en la marcha realizados por un autoproclamado forense podiatra (de Harley Street, Londres), basado en que la podología tiene más de un milenio de antigüedad y admisibilidad. Véase Cunliffe y Edmond, 2014: 327.

312 Véase e.g. $R v$ Lawless [1974] VR 398 and $R v$ O'Callaghan [1976] VR 676. 
Podemos observar un cierto grado de continuidad en las decisiones modernas. De hecho, en la apelación en Bennett v. Police, una decisión de la jurisdicción de common law de Australia del Sur, podría incluso sugerir un cierto grado de liberalización.

El recurrente fue identificado por un examinador de huellas dactilares, quien describió una huella dactilar encontrada en un computador de la casa allanada como «idéntica a la huella dactilar tomada del Sr. Bennett» y proveniente "de la misma persona» ${ }^{313}$. En la apelación, no hubo discusión sobre si el examinador estaba «calificado para expresar la opinión que dio» ${ }^{314}$. La decisión comienza con la Corte insistiendo en que «no hubo ninguna sugerencia de que el proceso de comparación que siguió el perito no sea reconocido o apropiado» ${ }^{315}$. Más bien, el abogado de Bennett se quejó de que el examinador no había proporcionado imágenes ni había mostrado las características que observó. Además, no había tomado notas de su comparación ${ }^{316}$. Esto significaba que la defensa no estaba en condiciones de determinar los hechos en los que se basaba su opinión ni en evaluar dicha opinión ${ }^{317}$.

En la apelación, el Presidente de la Corte Suprema de Australia del Sur señaló que la admisibilidad no se veía afectada por la (in)capacidad «para describir en detalle lo que observó el perito, o para producir una imagen o representación de lo que observó el perito» ${ }^{318}$. Estos fueron considerados como problemas que afectarían al valor de la prueba, no su admisibilidad ${ }^{319}$. La Corte indicó que la defensa «tuvo todas las oportunidades para someter a interrogatorio cruzado» al perito ${ }^{320}$. Además, el hecho de que la defensa no haya solicitado las imágenes oportunamente ni realizado un interrogatorio, fue un factor que la Corte consideró que debería tenerse en cuenta al valorar el mérito de la apelación ${ }^{321}$. Al final, la Corte se mostró satisfecha con la admisibilidad y la seguridad de la condena*, debido a la «indiscutida prueba de que cada huella dactilar mostraba características que, en su conjunto, permitían concluir

313 Bennett v. Police [2005] SASC 167, [2], [6].

314 Bennett, [5].

315 Bennett, [5].

316 Bennett, [11]. Durante el receso de almuerzo en el juicio oral, el examinador echó otra mirada a las huellas y los reportes, encontrando "más de 20 características que eran comunes e idénticas».

317 La referencia fue echa al caso UEL de Makita Pty. Ltd. v. Sprowles (2001) 52 NSWLR 705, [59]-[63]. Véase también Davie v. Magistrates of Edinburgh [1953] SC 34.

318 Bennett, [44].

319 Bennett, [44], [47]. Inicialmente, las imágenes se mostraban al jurado para que realizara la comparación con ayuda de los examinadores de huellas dactilares, pero más recientemente en Australia, los casos sugieren que son los examinadores quienes deben realizar directamente las comparaciones: $R$. v. Lawless [1974] VR 398. 425; S. V. Nala (1965) 4 SA 360, 362. Compare R. v.. O'Callaghan [1976] VR 676, 679 .

320 Bennett, [16].

321 Bennett, [47]. Véase también Dasreef Pty. Ltd. V. Hawchar [2011] HCA 21, [32].

* Nota de traducción: «Safety of conviction» o «safe conviction» es el criterio de apelación de las condenas, esto es, el apelante debe argumentar que se trata de una "unsafe conviction» dado que hubo ciertas irregularidades procesales que afectaron el fair trial. 
que son idénticas a las del acusado» ${ }^{322}$. No fue considerado «inequitativo, en un caso como este, dejar la carga al abogado para que interrogue [al examinador] sobre las características en las que basó su opinión» ${ }^{323}$. La decisión fue confirmada en una nueva apelación ante el pleno de la Corte.

La mayoría de las otras impugnaciones (también algo superficiales) a la prueba de huellas dactilares latentes se centraron en problemas secundarios, en lugar de los tipos de cuestiones recomendados por los científicos, que se analizaron en la sección 3.C. El interés jurídico estaba enfocado en omisiones y opacidades, al hecho de no documentar o proporcionar suficientes detalles en los informes (como en Bennett), o examinadores aventurándose a dar opiniones más allá de la identidad del sujeto, como la importancia o la antigüedad de las impresiones dactilares. La falta de impugnaciones sustanciales en Australia podría considerarse sorprendente dadas las varias condenas erróneas expuestas por las Comisiones Reales en la década de 1980 y, más recientemente, revisiones exitosas como Wood v. R., R. v. Gilham y R. v. Keogh ${ }^{324}$. El internacionalmente conocido caso de la muerte de Azaria Chamberlain (el «bebé dingo») resultó en una condena errónea para sus padres. Tras agotar las instancias de apelación previstas, una Comisión Real en 1986-1987 expuso problemas en todos los niveles de la investigación policial y de las ciencias forenses utilizadas. Sin embargo, las críticas de la Comisión a las prácticas policiales y científico-forenses no se extendieron muy lejos y las reformas hicieron relativamente poca diferencia práctica en muchas áreas del ejercicio forense ${ }^{325}$. La prueba de huellas dactilares quedó intacta. En la época de la Comisión Real, los diversos estados y territorios australianos, al igual que otros países avanzados, comenzaban a modernizarse mediante la introducción de sistemas informáticos para la recolección, el almacenamiento y la búsqueda de huellas dactilares.

A partir de 1995, junto con el Commonwealth (tribunales federales) y Nueva Gales del Sur (el estado más grande), varias jurisdicciones australianas introdujeron nuevas reglas probatorias. Influidas por las FRE estadounidenses, estas reglas fueron adoptadas lentamente por la mayoría (aunque no todos) de los estados y los territorios australianos. Una de las razones por la cual la prueba científico-forense no ha recibido impugnaciones más enérgicas es el rechazo formal, en muchas de las jurisdicciones más pobladas (por ejemplo, Nueva Gales del Sur y Victoria), de

322 Bennett, [53]. (cursivas añadidas). Las huellas dactilares nunca son idénticas. El problema es si las diferencias en las impresiones dactilares (causadas por variaciones en la presión, el sustrato, la condición de los dedos, la antigüedad y la conservación, etc.) son lo suficientemente similares para caracterizarlas como una coincidencia.

323 Bennett, [55].

324 Justice Morling, Royal Commission of inquiry into the Chamberlain Convictions (1987); C. Shannon, Royal Commission of Inquiry in Respect to the Case of Edward Charles Splatt (Government Printer, Adelaide, 1984); Woodv. The Queen (2012) 84 NSWLR 581; Gilham v. The Queen (2012) 224 A Crim R 22; R. v. Keogh [No 2] (2014) 121 SASR 307. Véase, en general Moles y Sangha, 2015.

325 Uno de los pocos legados sobrevivientes es el Instituto Nacional de Ciencia Forense, ahora financiado y controlado de manera abrumadora por las agencias policiales. 
la fiabilidad como requisito de admisibilidad ${ }^{326}$. A diferencia de la Corte Suprema de los EE. UU. en Daubert y Kumho, los tribunales australianos no han querido interpretar que la necesidad de incorporar la «fiabilidad» se encuentra en el requisito de que la opinión de los expertos debe estar «total o sustancialmente basada» en el "conocimiento especializado» (UEL art. 79) ${ }^{327}$. En Tang, la Corte de Apelaciones penales de Nueva Gales del Sur insistió en que el foco de atención debe estar en las palabras "conocimiento especializado" y no en la introducción de un concepto extraño como la «fiabilidad» ${ }^{328}$. Otra razón es la prohibición a los jueces de control de considerar la fiabilidad de la prueba o la credibilidad del testigo al considerar la exclusión de la prueba bajo la ponderación discrecional entre el valor probatorio y el prejuicio injusto, que se lleva a cabo conforme al art. $137^{329}$. A diferencia de todas las otras jurisdicciones analizadas aquí, Australia no exige que la parte que presenta una prueba científica o técnica demuestre su fiabilidad como condición de admisibilidad. Los tribunales australianos parecen depositar una confianza extrema en las garantías procesales.

\subsection{A manera de reseña}

Los resultados (y lecciones) más bien decepcionantes, aunque quizás saludables, de todas estas jurisdicciones es que los nuevos criterios de admisibilidad -al menos en relación con los procedimientos forenses de larga data, como las huellas dactilares latentes- parecen no haber hecho una diferencia significativa en su admisión o en la forma en que se presentan. La introducción de criterios de admisibilidad basados en la fiabilidad, junto con los llamados a los jueces de control para que filtren de manera más enérgica las pruebas e incluso los cambios en las comparaciones de huellas dactilares latentes gracias a la introducción de nuevas tecnologías, no produjeron muchas impugnaciones ni cambios en su admisibilidad o forma de presentación.

\section{BIBLIOGRAFÍA}

Alder, K., 2007: The Lie Detector. The History of an American Obsession, New York: Free Press. Beecher-Monas, E., 2007: Evaluating Scientific Evidence: An Interdisciplinary Framework for Intellectual Due Process, New York: Cambridge University Press.

Berger, M., 2003: «Expert Testimony in Criminal Proceedings: Questions Daubert Does Not Answer», en Seton Hall Law Review, 33.

— 2005: «What Has a Decade of Daubert Wrought? », en American Journal of Public Health, 95.

Bunn, G.,2012: The Truth Machine: A Social History of the Lie Detector, Baltimore: Johns Hopkins.

$326 R v$ Tang (2006) 65 NSWLR 681, [137]; Tuite v The Queen [2015] VSCA 148, [58]-[59].

327 EDMOND, 2014: 136.

328 Tang, [137]. De manera notable, la Corte [p. 138], se basó en la definición de "conocimiento" usada por la Corte Suprema de EE.UU. en Daubert y Kumho.

${ }^{329} I M M v$ The Queen [2016] HCA 14, que de manera inadvertida revocó Tuite v The Queen [2015] VSCA 148. 
Cheng, E. y Yoon, A., 2005: «Does Frye or Daubert matter? A study of scientific admissibility standards", en Virginia Law Review, 91.

Cole, S.A., 2001: Suspect Identities: A History of Fingerprinting and Criminal Identification: Harvard University Press.

- 2009: «A Cautionary Tale about Cautionary Tales about Intervention», en Organization, 16.

Cunliffe, E. y Edmond, G., 2014: «Gatekeeping in Canada: Mis-steps in Assessing the Reliability of Expert Testimony», en Canadian Bar Review, 92.

- 2018: "What have we learned? Lessons from Wrongful Convictions in Canada», en Ben Berger, et al (eds), To Ensure that Justice is Done: Essays in Memory of Marc Rosenberg, Toronto: Carswell.

Dror, I. et al, 2006: «Contextual Information Renders Experts Vulnerable to Making Erroneous Identifications», en Forensic Science International, 156.

EDmond, G., 2014: «The admissibility of forensic science and medicine evidence under the Uniform Evidence Law', en Criminal Law Journal, 38.

— et al, 2013: «Admissibility Compared: The reception of incriminating expert opinion (ie forensic science) evidence in four adversarial jurisdictions», en University of Denver Criminal Law Review, 3.

Edmond, G. y Roach, K., 2011: «A Contextual Approach to the Admissibility of the State's Forensic Science and Medical Evidence», en University of Toronto Law Journal, 61.

Edmond, G., Piasecki, E. y Carr, S., 2019: «Science Friction: Streamlined Forensic Reporting», en Oxford Journal of Legal Studies (forthcoming).

Evett, I. y Williams, R., 1996: «Review of the Sixteen Points Fingerprint Standard in England and Wales", en Journal of Forensic Identification, 46.

Faigman, D.L., Monahan, J. y Slobogin, C., 2014: «Group to Individual (G2i) Inference in Scientific Expert Testimony", en University of Chicago Law Review, 81.

Giannelli, P.C., 1980: «The Admissibility of Novel Scientific Evidence: Frye v United States, a Half Century Later' (1980), en Columbia Law Review, 80.

- 2004: «Ake v. Oklahoma: The Right to Expert Assistance in a Post-Daubert, Post-DNA World», en Cornell Law Review, 89.

Gudjonsson, G., 2002: The Psychology of Interrogations and Confessions: A Handbook, Chichester: Wiley.

Jasanoff, S., 1995: Science at the Bar: Law, Science and Technology, Harvard University Press.

Lawless, C., 2016: Forensic Science: A Sociological Introduction.

Lo Pucki, L., 1996: «Legal culture, legal strategy, and the law in lawyers' heads», en Northwestern University Law Review, 90.

Lynch, M. et al, 2008: Truth Machine: The contentious history of DNA finger-printing, University of Chicago Press.

Lynch, M. y Cole, S., 2005: «Science and Technology Studies on Trial: Dilemmas of Expertise», en Social Studies of Science, 35.

Martire, K. y Edmond, G., 2017: «Rethinking expert opinion evidence', en Melbourne University Law Review, 41.

Moles, R. y SAngha, B., 2015: Miscarriages of Justice: Criminal Appeals and the Rule of Law in Australia: LexisNexis.

Nobles, R. y Schiff, D., 2000: Understanding Miscarriages of Justice: Law, the Media, and the Inevitability of Crisis, Oxford: Oxford University Press.

Risinger, M., 2000: «Navigating Expert Reliability: Are Criminal Standards of Certainty Being Left on the Dock», en Albion Law Review, 64.

Roberts, P., 1998: «Expert Evidence in Criminal Proceedings: More Lessons from North America», en H Reece (ed.) Law and Science, Oxford: Oxford University Press.

— 2017: «Making forensic science fit for justice», en Australian Journal of Forensic Science, 49.

Saks, M. y Faigman, D., 2008: «Failed Forensics: How Forensic Science Lost Its Way and How It Might Yet Find It», en Annual Review of Law \& Social Science, 4.

SaKs, M. y Koenler, J.J., 2005: «The Coming Paradigm Shift in Forensic Identification Science', en Science, 309. 
Saks, M. y Spellman, B., 2016: The Psychological Foundations of Evidence Law, New York: New York University Press.

Sallavaci, O., 2016: «Streamlined reporting of forensic evidence in England and Wales: Is it the way forward?", en Evidence \& Proof, 20.

SENGOOPTA, C., 2003: Imprint of the Raj: How fingerprinting was born in colonial India, London: Macmillan.

StOCKDALE, M. y JaCKson, A., 2016: «Expert evidence in criminal proceedings: Current challenges and opportunities», en Journal of Criminal Law, 80.

Tangen, J., Thompson, M. y McCarthy, D., 2011: «Identifying Fingerprint Expertise», en Psychological Science, 22

Thompson, W., et al, 2017: Forensic Science Assessments: A quality and gap analysis - Latent fingerprint examination, Washington DC: AAAS.

Ulery, B., et al, 2011: «Accuracy and reliability of forensic latent fingerprint decisions», en Proceedings of the National Academy of Sciences, 108.

Walker, C. y Starmer, K., 1999: Miscarriages of justice: A review of justice in error Oxford.

WARD, T., 2013: «Expert Evidence and the Law Commission: Implementation without Legislation?», en Criminal Law Review, 561. 
